\title{
Ehl-i Hiref Maaş Defterlerinde Kayıtlı Tebrizli Sanatkârlar $(1526-1566)^{*}$
}

\author{
Murat Uluskan ${ }^{* *}$ \\ $\ddot{O}_{z}$
}

Osmanlı saray sanatkârları ile ilgili başvurulacak kaynakların başında Ehl-i hiref maaş defterleri gelmektedir. Sanatçıların maaşları, unvanları, menşeleri, kuruma giriş şekilleri ve aile bilgileri gibi verilerin kaydedildiği bu defterler, sanatçların kariyerleri ve ölüm tarihleriyle birlikte hangi sanat dalında kaç kişi çalıştıklarına dair bilgileri de içermektedir. Ehl-i hiref maaş defterlerinden izlenebildiği kadarıla, kuruma alınan sanatçıların bazılarının çeşitli savaşlar sonucunda ülkeye getirilmiş usta sanatkârlar olduğu anlaşılmaktadır. Fatih Sultan Mehmed döneminde (1451-1481) kazanılan Otlukbeli Savaşı'ndan (1473) sonra Akkoyunlu bazı ilim ve sanat erbabı getirilip Osmanlı Devleti'nde görevlendirilmeye başlanmıştr. II. Bayezid döneminde (1481-1512) yine kuruma çok sayıda sanatçı alındığı maaş defterlerine düşülen notlardan anlaşılmaktadır. Ayrıca Yavuz Sultan Selim'in (1512-1520) Safevî hükümdarı Şah İsmail’i Çaldıran Savaşı'nda (1514) yenilgiye uğratmasından sonra Tebriz'de Şah'ın özel hizmetinde görevli ve saray dışında serbest çalışan ünlü sanatkârları toplatmış olduğu bilinmektedir. Bu sanatçlar sefer dönüşünde kışın geçirildiği Amasya'ya getirtilmiş, İstanbul'a gelindiğinde ise sarayın Ehl-i hiref teşkilatında ilgili sanat sınıflarında görevlendirilmiştir. Bu çalışmada, Kanuni Sultan Süleyman dönemine (1520-1566) ait günümüze ulaşan en eski Ehl-i hiref maaş defterlerinde kayıtlı Tebrizli sanatkârların isimleri, maaşları, sanat sınıfları, Osmanlı hizmetine giriş tarihleri ve hizmet süreleri incelenmektedir.

Anahtar Kelimeler: Osmanlı Sarayı, Osmanlı Sanatı, Ehl-i Hiref, Tebriz, Azerbaycan, Akkoyunlu, Safevi, İran, Acem, Sanatkâr,

* Bu makale, 11-12 Temmuz 2019 tarihleri arasında Bakü'de Azerbaycan İlahiyat Enstitüsü, Şarkiyat Enstitüsü ve IRCICA tarafindan ortaklaşa düzenlenen "Kafkasya'da İslam Medeniyeti" konulu sempozyumda sunulan aynı başlıklı yayımlanmamış sözlü bildirinin genişletilmiş hâlidir.

** Prof. Dr., Marmara Üniversitesi, Fen-Edebiyat Fakültesi, Tarih Bölümü, İstanbul/TÜRKIYE, muluskan@marmara.edu.tr ORCID: 0000-0002-9891-565X

DOI: 10.37879/belleten.2021.849

Makale Gönderim Tarihi: 27.05.2020 - Makale Kabul Tarihi: 02.08 .2021

Belleten, Aralık 2021, Cilt: 85/Sayı: 304; 849-887 


\title{
Artists from Tabriz Registered in Ehl-i Hiref Salary Books (1526-1566)
}

\begin{abstract}
The Ehl-i Hiref salary books are the main sources to be consulted on Ottoman palace artists. These notebooks, containing data such as the artists' salaries, titles, origins, ways of joining the palace and family information, include data about the artists' careers and death dates, as well as how many people they worked with in any art branch. According to these salary books of the Ehl-i hiref, it is understood that some of the artists who were taken into the institution were master craftsmen brought to the country as a result of various wars. In the aftermath of the Battle of Otlukbeli (1473), which was won during the reign of Sultan Mehmed the Conqueror (1451-1481), some scholars and artists from Akkoyun were brought and started to be employed in the Ottoman Empire. At the reign of Sultan Bayezid II (1481-1512), it is understood from the notes obtained from the salary books that many artists were taken under Sultan's service. It is also known that following the triumph of Sultan Selim (15121520) against Shah Ismail, the Safavid ruler, in the Battle of Chaldiran (1514), the Sultan employed famous artisans from Tabriz who previously worked either in the private service of the Shah or as freelancers. These artists were brought to Amasya, where they spent the winter on the return of the campaign, and as soon as they came to Istanbul, they were assigned to the relevant art classes in the Ehl-i hiref organization of the palace. In this study, the names, salaries, art classes, dates of entry into Ottoman service and service periods of Tabriz artists registered in the earliest Ehl-i hiref salary books from the period of Suleiman the Magnificent (1520-1566) are examined.
\end{abstract}

Keywords: Ottoman Palace, Ottoman Art, Ehl-i Hiref, Tabriz, Azerbaijan, Aqqoyunlu, Safavid, Iranian, Persian, Artist

\section{Giriş}

Osmanlı sarayının bîûn denilen dış hizmet birimleri arasında yer alan ve imparatorluğun sanatsal faaliyetlerinin yürütüldüğü bir teşkilat olarak Cemâat-i Ehl-i Hiref-i Hâssa adıyla faaliyet gösteren Saray sanatkârları zümresi, bünyesinde barındırdığı sanatçı ve zanaatçı sınıflarıyla sarayın ihtiyaç ve istekleri doğrultusunda eserler üreterek Osmanlı sanatının gelişip şekillenmesinde öncü rol oynamıştır. Sayıları, yaptıkları işe ve ihtiyaca göre değişen bu sanatkârların teşkilatına dair en önemli bilgiler Ehl-i hiref mevâcib (maaş) defterlerinde bulunmaktadır. Osmanlı arşiv kayıtlarında 16. yüzyıl başlarından 18. yüzyıl sonlarına dek örneklerine 
rastlanan bu defterlerde, sanatkârların ve yetişmekte olan öğrencilerinin isimleri, menşeleri, yevmiye üzerinden ödenen maaşları ve ölüm kayıtları yer alırdı. Teşkilata dair tüm resmî yazışmalar, bağlı bulundukları Enderun Hazinedarbaşısı'nın arzıyla yapılır, üç aylık maaşları da onun vasıtasıyla dağıtılırdı ${ }^{1}$.

Sultan II. Mehmed döneminde (1451-1481) önce Edirne Sarayı ve ardından İstanbul'un fethi sonrası inşa edilen Eski ve Yeni Saraylarda başlayan Ehl-i hiref yapılanması, bir teşkilat olarak esas gelişimini Sultan II. Bayezid devrinde (14811512) gösterdi ${ }^{2}$. Şüphesiz bunda, hükümdar ve çevresinin sanatı ve sanatçıyı destekleyen, himaye eden politikalarının önemi büyüktü . Fatih’in nakkaşlar için saray bünyesinde bir nakkaşhane tesisi, portre ve madalyonlarını yaptırmak için İtalya'dan sanatçılar davet etmesi, Otlukbeli Savaşı'ndan (1473) sonra Akkoyunlu bazı ilim ve sanat erbabını getirtmesi Osmanlı sanatının 16. yüzyılda ulaştı̆̆ı zirvenin başlangıcını oluşturdu. II. Bayezid devrinde sanat ve sanatçıy himaye Fatih dönemiyle kıyaslanamayacak derecede arttı. Hükümdarlığı öncesi 27 yıl valilik yaptığı Amasya'daki kültürel zenginlik ve üretilen eserlerin yoğunluğu tahta çıktığında da sürdü4. Sultan I. Selim (1512-1520) ve I. Süleyman (1520-1566) devirlerinde doğu ve batı sınırlarında yapılan yeni fetihler ve kazanılan askerî zaferler sonucu Osmanlı Sarayında istihdam edilen sanatkâr sayısı artmaya devam etti. Kanûnı̂’nin 46 yıllık saltanatı ise Ehl-i hiref teşkilatının tam manasıyla gelişimini tamamladığı bir dönem oldu ${ }^{5}$.

Osmanlı coğrafyasında Tebrizli sanatkârların izine ise İstanbul'un fethinden önce Bursa ve Edirne'de rastlanmaktadır. Timur'un, Ankara Savaşı'nın (1402)

1 İsmail Hakkı Uzunçarș̣lı, "Osmanlı Sarayı'nda Ehl-i Hıref (Sanatkârlar) Defterleri”, Belgeler, C 11/S. 15 (1986), s. 23; İsmail Hakkı Uzunçarşıll, Osmanh Devletinin Saray Teşkilâtı, Ankara 1988, s. $316,318$.

2 Filiz Çağman, "Mimar Sinan Döneminde Saray'ın Ehl-i Hiref Teşkilâtı", Mimar Sinan Dönemi Türk Mimarlığr ve Sanatı, İstanbul 1998, s. 74.

3 Bu konuda geniş bilgi için bk. Hilal Kazan, XVI. Asırda Sarayın Sanatı Himayesi, İstanbul 2010.

4 Zeren Tanınd, Türk Minyatür Sanat, İstanbul 1996, s. 12-13.

5 Ehl-i hiref teşkilatı ve defterleri üzerine yapılan araştırmalar son on beş yılda artış göstermiştir. Bahattin Yaman, makalelerinin yanı sıra yayımladı̆̆ı kitapla da bu artışa öncülük etmiştir. Bk. Osmanlı Saray Sanatkârlan 18. Yüzylla Ehl-i Hiref, İstanbul 2008. Çoğunluğu Yüksek Lisans tezi olarak hazırlanan çalışmalar arasında ise iki doktora tezi öne çıkmaktadır. Süleyman Kırımtayıf'ın 1998 yllında hazırladığı tezin (XV. ve XIX. Yüzynllar Arasında Osmanlı Saray Sanatı Teşkilatı, İstanbul Teknik Ün. Sosyal Bilimler Ens. Yayımlanmamış Doktora Tezi, İstanbul 1996) ardından yapılan en güncel çalı̧̧̧ Sakine Akcan Ekici'ye aittir. Bk. 17. Yüzyllda Osmanh Devleti’nde Ehl-i Hiref-i Hâssa Teşkilatı Birimleri ve Yapısal Özellikleri, İstanbul Ün. Sosyal Bilimler Ens. Yayımlanmamış Doktora Tezi, İstanbul 2018. 
ardından Semerkant'a dönerken beraberinde bazı âlim ve sanatkârları götürdüğü bilinmektedir. Bunlar arasında, sonraki tarihlerde Bursa Yeşil Külliye’nin (1419-1424) süslemesinde çalışmış olan Nakkaş Ali de bulunmaktadır. Nakkaş Ali, Semerkant'ta nakkaşlık sanatını öğrenmiş ve 1410’lu yıllarda Bursa'ya dönerken beraberinde başka Tebrizli ustaları da getirmiştir. Elbette bunda, on bir yıl süren taht mücadelesinin ardından başa geçen Sultan I. Mehmed (1413-1421) ve veziri Hacı İvaz Paşa'nın sanatçıyı davet, himaye ve destek politikasının tesiri büyüktür. Tebrizli usta grupları, Sultan II. Murad devrinde (1421-1451) Bursa ve Edirne'de inşa edilen yapılarda da çalışmalarını sürdürmüşlerdir ${ }^{6}$.

Bu dönemde Karakoyunlu hükümdarı Cihan Şah'ın (1438-1467) hâkimiyetinde olan Tebriz, 1469 yılında Akkoyunlu hükümdarı Uzun Hasan tarafindan ele geçirildi' ${ }^{7}$ Başkentini Diyarbakır'dan Tebriz'e taşıyan Uzun Hasan zamanında şehir, devrin âlim, şair ve sanatkârlarının himaye görüp toplandığı bir kültür ve sanat merkezi haline geldi ${ }^{8}$. Osmanlılarla yapılan 1473 Otlukbeli Savaşı ile Akkoyunlulara hizmet eden İsfahanlı, Şirazlı, Tebrizli sanatçılar ve astronom Ali Kuşçu gibi bilginler İstanbul'a göç etseler de Tebriz sanatçlar için bir merkez olma hüviyetini kaybetmedi. 1501 yılında Akkoyunlu hâkimiyetine son vererek devletini kuran Safevî hükümdarı Şah İsmail, İran coğrafyasının meşhur sanatçılarını Tebriz'deki sarayında istihdam ederek himayesi altına aldı ${ }^{9}$.

Tebriz ve civarından Anadolu'ya ilim ve sanat erbabının göçü aslında Selçuklular zamanında başlamıştı. Moğolların 13. yüzyıl başlarında bölgeye düzenlediği ilk akınlar sonrasında birçok âlim, sanatkâr ve tüccar Anadolu’ya göç etmek zorun-

6 Z. Tanındı, age., s. 8. Sultan I. Mehmed ve II. Murad dönemlerinde Bursa ve Edirne'de inşa edilen yapılarda çalışan Tebrizli usta grupları hakkında bk. Mustafa Çağhan Keskin, "Siyasi-Kültürel İlişkiler Çerçevesinde Tebrizli Çini Ustalarının Anadolu Yolculuğu (1419-1433)" Belleten, S. 279 (Ağustos 2013), s. 445-465; Mustafa Beyazıt, "Erken Osmanlı Devri'nde Tebrizli Usta Gruplarının İzi Nasıl Sürülmeli?”, History Studies, C 6/S. 3 (Nisan 2014), s. 45-70.

7 Ali Sinan Bilgili, "Tebriz”, Türkiye Diyanet Vakfi İslâm Ansiklopedisi (TDVİA), G 40, İstanbul 2011, s. 219.

8 İsmail Hakkı Uzunçarşıll, Anadolu Beylikleri, Akkoyunlu ve Karakoyunlu Devletteri, Ankara 1988, s. 194, 225; Faruk Sümer, "Akkoyunlular", TDVIA, C 2, İstanbul 1989, s. 274. Tebriz, ticaret yolları üzerinde bulunması ve iktisadî hayatın canlılığı dolayısıyla Selçuklulardan itibaren önemi giderek artan bir ticarî merkez ve sanatkârların da yoğun olarak faaliyet gösterdiği bir şehirdi. Bu konuda bk. Yaşar Bedirhan, "XI. XIV. Yüzylllarda Kafkasya Şehirlerinde İktisadi ve Sosyal Hayat (Tebriz Örneği), Akademik Sosyal Araşttrmalar Dergisi, S. 40 (Şubat 2017), s. 181-210; Yaşar Bedirhan, "Ortaçağda Kafkasya Türk Şehirlerinde Esnaf Teşkilatları (Tebriz Örneği)", Bingöl Üniversitesi Sosyal Bilimler Enstitiusü Dergisi, G 7/S. 13 (2017), s. 223-236.

9 Z. Tanind, age., s. 12-13, 18-19.

Belleten, Aralık 2021, Cilt: 85/Sayı: 304; 849-887 
da kaldı. Bu durum Anadolu'daki ilim, kültür ve sanat ortamının genişlemesine önemli katkılar sağladı ${ }^{10}$. İran'daki siyasî rekabetin 14 . yüzyıl sonlarından itibaren kültürel alana da yansıması, hükümdarlar nezdinde bilim adamları ve sanatçları himayenin önemini daha da artırdı ${ }^{11}$. Savaşların ardından göçürülenler dışında, Tebrizli sanatkârların 15. yüzyıldaki hami tercihlerini belirleyen en önemli etken ise kendilerine sunulan cazip teklif ve davetlerdi. Fatih Sultan Mehmed, İstanbul'u aynı zamanda bir kültür ve sanat başkenti haline getirebilmek için İran başta olmak üzere doğunun ve batının meşhur bilim adamlarını ve sanatkârlarını sarayına davet etti. Hediyeler göndererek ve yüksek ücretler ödeyerek çalışmalarını Osmanlı sarayına sunmaları için onları teşvik etti. Şah İsmail'in 1501 yılında Şiiliği Safevî devletinin resmî mezhebi olarak ilan etmesi de İran'daki Sünni âlim ve sanatkârların Osmanlıya göçünü hızlandırdı. Bunda, şehzadeliğinden itibaren sanata ve sanatçıya verdiği destekle bilinen Sultan II. Bayezid’in hamiliği önemli bir etkendi ${ }^{12}$.

23 Ağustos 1514 tarihinde vuku bulan Çaldıran Savaşı ${ }^{13}$, sonuçları itibariyle Osmanlıya doğunun kapılarını açan büyük bir zaferdi. Elde ettiği galibiyet sonrası Sultan Selim, Safevî başkenti Tebriz'e girdiği 6 Eylül tarihinden bir hafta önce, 30 Ağustos'ta Vezir Dukakinzâde Ahmed Paşa ve Defterdar Pîrî Çelebi'yi, SekbanbaŞ1 emrindeki beş yüz yeniçeri ile birlikte şehre gönderdi. Görevleri, şehrin idaresini ele alıp güvenliğini sağlamak ve Şah İsmail'in geride bıraktığı kıymetli eşyayı tespit edip muhafaza altına almaktı ${ }^{14}$. Bu doğrultuda, Tebriz'deki Heşt Behişt Sarayı'nda bulunan eşyalar ve sanatkârlar 2 Eylül tarihi itibariyle kayıt altına alındı ${ }^{15}$.

10 Yaşar Bedirhan, XII. ve XIII. Yüzyılda Kafkasya'dan Anadolu’ya Göç Eden İlim ve Fikir Adamları", Turkish Studies, C 9/S. 7 (2014), s. 193-213.

11 Tuba Işınsu Durmuş, "Siyasi Rekabetin Bir Enstrümanı Olarak Ortaçağ'da Sanat", Divan Edebiyatı Araştrmalan Dergisi, S. 12 (2014), s. 65-68.

12 Tofigh Heiderzadeh, "İran Alimlerinin Osmanlı Devletine Gelişi ve Osmanlı Bilimine Katkıları (Timur Döneminin Başından Safevi Döneminin Sonuna Kadar)", Ingilizce'den çeviren: Aysu Albayrak, Osmanh Bilimi Arasttrmalar, S. 2 (1998), s. 212, 216-217.

13 Çaldıran Savaşı hakkında geniş bilgi için bk. Feridun Emecen, Yavuz Sultan Selim, İstanbul 2016, s.124-164.

14 Haydar Çelebi Rûznâmesi (Feridun Bey, Münşeâtiu’s-Selâtîn, C I içinde, İstanbul 1274, s. 463 (9 Receb 920 / 30 Ağustos 1514); Celâl-zâde Mustafa, Selim-nâme, haz. Ahmet Uğur-Mustafa Çuhadar, Ankara 1990, s. 154; Hoca Mehmed Sadettin Efendi, Tâcüt-Tevârîh, G 2, İstanbul 1280, s. 279. İdrîs-i Bidlîsî, kendisinin de içinde bulunduğu heyetteki yeniçeri sayısını dört yüz olarak vermektedir (İdrîs-i Bidlîsî, Selîm Şâh-Nâme, haz. Hicabi Kırlangiç, Ankara 2016, s. 243).

15 Cumhurbaşkanlı̆̆ı Osmanlı Arşivi (BOA), Topkapı Sarayı Müzesi Arşivi (TSMA), D.10734 (12 Receb 920 / 2 Eylül 1514). Bu tarihi takip eden günlerde hazırlanan daha küçük çaplı bir liste 
Hazırlanan defterde; Zerger Mirek ve Hüdâbahş oğlu Maksud Ali, Zerkeş Ahmed, Zernişânî Derviş Ali, Zerdûz Han Ali-i Horasânî, Hoca Kici Beğ, Hâtun Beğ, Hâtun, Aziz Paşayî, Bahâaddin Ali, Muhib Paşayî ve Habîbe Sultan, Kâtip Mevlânâ Fethullah, Nakkāş Şah Kulu, Hüseyin-i Rûmî, Şah Mahmud, Hüseyin, Şemseddin Ali, Ali Han ve Hoca Beğ gibi usta sanatkârların üzerinde çalıştıkları kıymetli eserlerin listesi verildi. İçlerinde, Nakkaş Ali Han tarafindan süslemeleri yapılıp bir-iki aylık işi kaldığı belirtilen ak, kızıl ve yeşil renkte üç otak da bulunmaktaydı. İlaveten, cebecilerden Seyyid Kutbeddin Haydar ve Cafer Ali, Siperdûz Hoca Hâfiz-1 Horasânî, Kûfteger Muhammed Can, hayyâtlardan Cafer, Hüseyin ve Abdüssamed'in çalışmaları listelendi. Enderun'da bulunan irili ufaklı pek çok sandık eşyası, Mehterhane'de mevcut otak, hayme ve sâyebânlar ile Şah İsmail'in beğlerine ait olup Ehl-i hiref zimmetinde kalan eşyalar kaydedildi. Son olarak da sarayda bulunan farklı sanat sınıflarına mensup bir grup sanatkârın ismine yer verildi.

Tablo 1: Şah İsmail’in Sarayında Bulunup Kaydedilen Bir Grup Sanatkârın Listesi

\begin{tabular}{|c|c|c|}
\hline Sinifi & Adlari & Sayısı \\
\hline Zernişâniyân & $\begin{array}{l}\text { İsmail zernişânî, Üstâd Pîr Ali, Şemseddin Ali, } \\
\text { Üstâd Kāsım, Cemaleddin Hüseyin }\end{array}$ & 5 \\
\hline Zergerân & $\begin{array}{l}\text { Hoca Hüseyin Horasânî, Derviş Ali, Üstâd Maksud Ali, } \\
\text { Üstâd Emirhan }\end{array}$ & 4 \\
\hline Siperdûzân & $\begin{array}{l}\text { Mîr İbrahim Tebrîzî, Hâfız Horasânî-Bir üstâd şâkirdi vardır, } \\
\text { Abdüllatif siperdûz, Hacı Muhammed birâder-i O }\end{array}$ & 5 \\
\hline Cebeciyân & $\begin{array}{l}\text { Seyyid Kutbeddin, Ali Cafer, Seyyid Mahmud Tebrîẑ, Fah- } \\
\text { reddin Ahmed Horasân } \hat{\imath}\end{array}$ & 4 \\
\hline Hayyâtîn & $\begin{array}{l}\text { Cafer Rûmî, Üstâd Melek hayyât, Üstâd Ali damgaŷ̀, Üstâd } \\
\text { Seydî emrencî }\end{array}$ & 4 \\
\hline Kârdgerân & Birâder-i Derviş Ali, Üstâd Hamza Rûmî & 2 \\
\hline Hakkâkân & Üstâd Şirem, Hüseyin hakkâk & 2 \\
\hline Haymedûzân & Mirza Yâr Ali haymedûz & 1 \\
\hline Zerdûzân & $\begin{array}{l}\text { Han Ali zerdûz, Aziz Paşayî zerdûzbe, Gulâmân-1 şâkird-i } \\
\text { Han Ali zerdûz-üç nefer }\end{array}$ & 5 \\
\hline
\end{tabular}

de TSMA, D.9608'de kayıtlıdır. Defterlerde kayıtlı tüm kıymetli eşya ve sanatkâr listeleri için bk. Vural Savaş, "Heşt Behişt Sarayı'ndan Topkapı Sarayı'na: Şah İsmail'in, Çaldıran Savaşı’ndan Sonra Alıkonulan Hazine ve Eşyaları", Toplumsal Tarih, S. 208 (Nisan 2011), s. 24-36. Bu çalışma, gözden geçirilip genişletilerek yeniden yayımlanmıştır. Bk. Vural Savaş, "From Tabrız to Istanbul: Goods and Treasures of Shāh Ismāîil Looted After The Battle of Chāldırān", Studia Iranica, S. 44/2 (2015), s. 227-276. 


\begin{tabular}{|c|c|c|}
\hline Abâyîbâfân & Zeyneddin Ali Tebrîzî, Üstâd Ahî Tebrîzî & 2 \\
\hline Mücellidân & Şeyhzâde Zeyneddin Ali, Sa'deddin müzehhib & 2 \\
\hline Kannâdân & Üstâd Şah Muhammed kannâd & 1 \\
\hline $\begin{array}{l}\text { Nayzenân ve } \\
\text { Gûyendegân }\end{array}$ & $\begin{array}{l}\text { Mîr Ahmed Tebrîzî nayzen, Ali Han nayzen, Sultan Hüseyin } \\
\text { avvâd, Nimetullah çengî, Şah Kulu Horasânî kamançê̂, } \\
\text { Muhammed Fâid avvâd, Hâfiz Muhammed hânende, } \\
\text { Mahmud sipâhçeî hânende }\end{array}$ & 8 \\
\hline Nakkāşân & $\begin{array}{l}\text { Ser-nakkāsâân SSah Mansur Tebrîzî, Abdülganî, Hüseyin } \\
\text { Kazvînı̂ nakkăs, Şah Kulu nakkās, Hacı Beğ, Şeyhî Beğ }\end{array}$ & 6 \\
\hline Müneccim & Hoş Mevlânâ Rûşenî müneccim & 1 \\
\hline Kâtip & Seyyid Şemseddin Muhammed kâtib, Hoş Sultan Ali kâtib & 2 \\
\hline Toplam & & 54 \\
\hline
\end{tabular}

Tebriz'de dokuz gün kalan Sultan Selim, Amasya'da kışlamak üzere 15 Eylül tarihinde şehirden ayrıldı. Yola çıkmadan üç gün önce de kentin ileri gelenlerinin, meşhur sanatkâr ve tüccarlarının, Şah'ın Horasan'dan Tebriz'e sürdükleri de dâhil olmak üzere, aileleriyle birlikte İstanbul'a göçürülmesi emrini verdi ${ }^{16}$. Kapıkulu askerlerinin korumasında yola çıkan bini aşkın kişi ${ }^{17}$, Amasya'da geçirdikleri kışın ardından 1515 yılının Mart ve Nisan aylarında peyderpey, kafileler halinde İstanbul'a gönderildi ${ }^{18}$. Başkente getirilerek Saray hizmetine alınan sanatkârların

16 Haydar Çelebi Rûznâmesi (Feridun Bey, Münşe âtü’s-Selâtîn, C I içinde, s. 463); Celâl-zâde Mustafa, Selim-nâme, s. 155; Kemal Paşazâde, Tevârih-i Âl-i Osman, IX. Defter, haz. Ahmet Uğur, The reign of Sultan Selim I in the light of the Selim-nâme literature, Berlin 1985, s. 122-123; Hoca Sadettin Efendi, Tâcü't-Tevârîh, C 2, s. 282. Bu konuda ayrıca bk. Şehabettin Tekindağ, "Yeni Kaynak ve Vesikaların Işı̆̆ı Altında Yavuz Sultan Selim’in İran Seferi”, İstanbul Üniversitesi Edebiyat Fakültesi Tarih Dergisi, C 17/S. 22 (1967), s. 71-73.

17 İdrîs-i Bidlîsî, Selîm Şâh-Nâme, s. 250, 254. Tebriz'den göç ettirilenlerin sayısı hakkında kaynaklardaki bilgiler farklılık göstermektedir. Lütfi Paşa 200 hane (Kayhan Atik, Lütfi Paşa ve Tevârih-i Âl-i Osman, Ankara 2001, s. 219) ve Hoca Sadettin 1000 kişi (Tâcü't-Tevârîh, C 2, s. 282) ile İdris-i Bidlîsî’ye en yakın ve makul sayıları verirken, Muhyî Çelebi 1700 (Selim-nâme, Konya Koyunoğlu Müzesi Kitaplığı, nr. 13335, vr. 68b), İbn-i Kemal de 2000 hanenin (Ali Kökoğlu, Kemal Paşa-zâade’nin Selim-nâmesi, Erciyes Üniversitesi Sosyal Bilimler Enstitüsü Yayımlanmamış Yüksek Lisans Tezi, Kayseri 1994, s. 164-165) aileleri ve eşyalarıyla birlikte İstanbul'a sürüldüğünü belirtmektedir. İran kaynaklarında ise bu sayı birkaç yüz kişi olarak ifade edilmektedir. Bk. Nizameddin Mücir Şeybani, Teşkil-i Şâhenşâhî-i Safaviyye, Tahran 1346, s. 208'den naklen Farrokh Malekzadeh, "İstanbul Topkapı Sarayı Müzesinde Bulunan Şah İsmail-i Safevi’ye Ait Kupa", İstanbul Üniversitesi Tarih Enstitüsü Dergisi, S. 7-8 (1976-1977), s. 268.

18 Sancak beyi, azep, sipahi, silahtar ve zeamet sahibi askerlere teslim edilen Tebriz sürgünlerinden önemli bir kısmının gruplar halinde listelendiği kayıtlar yayımlanmıştır. Bk. Hüseyin Arslan, Osmanl’da Nüfus Hareketleri (XVI. Yüzyll) Yönetim, Nüfus, Göçler, İskânlar, Sürgünler, İstanbul 2001, s. 325333. Eserde, kullanılan arşiv kaynağı "D.BŞM.d. 36806, s. 648-663" olarak belirtilmiştir. Ancak 
pek çoğu, zaman içerisinde Ehl-i hiref teşkilatının ilgili sanat sınıflarına kaydedildi. Çalışma konumuzun esasını da işte bu sanatçılar yani günümüze ulaşan en erken tarihli Ehl-i hiref maaş defterlerinde (1526-1566) kayıtlı Tebrizli sanatkârlar oluşturmaktadır. Amacımız, bu defterlerdeki verilerden hareketle sanatçlların isimlerini, kuruma giriş şekillerini ve tarihlerini, aile bilgilerini, maaşlarını, hizmet sürelerini, yaklaşı ölüm tarihlerini ve hangi sanat dalında kaç kişi çalıştıklarını tespit edebilmektir.

Araştırmamızın ana kaynağı ve başlangıç noktası 1526 tarihli Ehl-i hiref teftiş defteridir ${ }^{19}$. Elimizdeki en erken tarihli defter oluşu ve içerik bakımından başka bir örneğine rastlanmayışı bu defteri eşsiz kılmaktadır. Tutulduğu tarih itibariyle Sultan II. Bayezid, I. Selim ve I. Süleyman devri sanatkârlarının isim, köken ve kuruma intisaplarına dair verdiği bilgiler son derece kıymetlidir. Tebrizli sanatkârların Osmanlı sarayına mensubiyetleri de en net ve doğru şekilde bu defterde görülmektedir. O yüzden, çalışmamızın başlangıcı ve hazırladı̆̆ımız sanatkâr listelerinin temeli buradan elde edilen verilere dayanmaktadır. Tespit edilen sanatkârların izleri ve kuruma sonradan dâhil olanların isimleri ise Kanunî döneminde tutulmuş $1545^{20}, 1557-58^{21}, 1564^{22}$ ve $1566^{23}$ tarihli diğer Ehl-i hiref defterlerinden takip edilmiştir. Tebriz'den getirilen az sayıdaki Horasan, Merv, Şiraz, İsfahan, Çerkes ve Gürcü kökenli sanatkârlar da ayırım yapılmaksızın çalışma kapsamına alınmıştır. Safevî hâkimiyetindeki bölgelerden geldiklerine dair haklarında hiçbir açıklama bulunmayanlar ise değerlendirme dışı tutulmuştur.

yazarın kaynak olarak kullandığı bu defter, Cumhurbaşkanlığı Osmanlı Arşivi (BOA)'nde "Bâb-ı Defterî Başmuhasebe Kalemi Defterleri (D.BŞM.d.)" fonunda değil, "Bâb-1 Defterî Müteferrik Defterler (D.M.d.)" fonunda kayıtlıdır.

19 BOA, TSMA, D.9706/1 (Rebî́ülâhir 932 / 15 Ocak-12 Şubat 1526). Yayımlanan bu defter için bk. İsmail Hakkı Uzunçarşılı, "Osmanlı Sarayı'nda Ehl-i Hiref (Sanatkârlar) Defterleri”, Belgeler, G 11/S. 15 (1986), s. 23-65. Osmanlı Saray Teşkilâtı ve Sanat Tarihi araştırmalarında başvuru eseri niteliği taşıyan bu çalışmada, zernişânî sınıfiyla ilgili başlı̆̆ın atlandığı (s. 38'de İsmail Tebrîzî ile başlayan liste) ve sanatkârların Ehl-i hiref defterine kaydedildiği tarihlerle alâkalı hatalı okumaların olduğu bilinmelidir.

20 BOA, TSMA, D.9706/4 (Muharrem-Rebî‘ülevvel 952 / 15 Mart-1 1 Haziran 1545). Yayımlanan bu defter için bk. Bahattin Yaman, "1545 Yılı Osmanlı Saray Sanatkârları", Belleten, C LXXII/S. 264 (Ağustos 2008), s. 501-534.

21 BOA, TSMA, D.9612 (Muharrem-Zilhicce 965 / 24 Ekim 1557-13 Ekim 1558). Yayımlanan bu defter için bk. Bahattin Yaman, "1557 Tarihli Ehl-i Hıref Defterine Göre Osmanlı Saray Sanatkârları", Kök Araştrrmalar, C 8/S. 2 (Güz 2006), s. 5-38.

22 BOA, TSMA, D.808 (Şevval 971-Rebî́ülevvel 972 / 13 Mayıs-5 Kasım 1564).

23 BOA, Mâliyeden Müdevver Defterler Tasnifi (MAD.d.), 6196, s. 148-160 (Muharrem-Rebî́ülevvel 974 / 19 Temmuz-15 Ekim 1566). 
Bu çalışmada, Tebrizli sanatkârların hangi üslupta eserler verdikleri, ne tür projelerde yer aldıkları, bir ekol oluşturup oluşturmadıkları, bulundukları sanat sınıfina ve Osmanlı sanatına katkıları gibi sanat tarihçilerinin uzmanlık sahalarına giren konular ele alınmamaktadır. Bir teşkilat tarihi araştırması olan makalemizde, öncelikle Tebrizli sanatkârların Osmanlı sarayına mensubiyetlerinin arttığı Sultan II. Bâyezid ve I. Süleyman devirleri arasındaki Ehl-i hiref sayıları aydınlatılmaya çalışılmıştır. Ardından da Tebrizli sanatçıların Ehl-i hirefe nasıl ve ne zaman dâhil oldukları, öncesinde istihdam edildikleri saray birimleri, sayıları, teşkilat içerisindeki oranları ve hangi sınıflarda yoğunlaştıkları Kanunî dönemi verilerinden hareketle oluşturulan sanatkâr listesi üzerinden tespit edilerek değerlendirmelere gidilmiştir.

\section{Ehl-i Hiref Sınıfları ve Sayıları (1501-1526)}

Ehl-i hiref maaş defterlerinde kayıtlı sanatkârların sayısı ve mensup oldukları sanat sınıfları hakkında bugüne dek ulaşılabilen en eski belge, Sultan II. Bayezid dönemine ait olduğu bilinen tarihsiz bir mevâcib defteridir. Yaptığımız inceleme neticesinde, 907-910 (1501-1505) yılları arasındaki dört yıldan birine ait olduğunu tespit ettiğimiz bu yıllık maaş icmal defterinde ${ }^{24}$ Ehl-i hiref mevcudu 360 olarak belirtilmiştir. Sanatçı isimlerinin yer almadığı, 42 sanat sınıfinın adı, mensuplarının sayısı, aylık ve yıllık ödenen maaş miktarının yazılı olduğu defterde; hattatlar (8 kişi), güreşçiler (12 kişi), marangozlar ile çıkrıkçılar (mimarlarla birlikte 21 kişi) Kanunî dönemi kayıtlarından farklı olarak ehl-i hiref dışında tutulmuştur. Ömer Lûtfi Barkan tarafindan yayımlanan bu kıymetli belge, önemine binaen tekrar

24 BOA, TSMA, D.9587; Ömer Lûtfi Barkan, "H.933-934 (M.1527-1528) Malî yılına ait bir bütçe örneği”, İstanbul Üniversitesi İktisat Fakültesi Dergisi, G 15/S. 1-4 (Ekim 1953-Temmuz 1954), s.308-311. Defterdeki kayıtlar, tutulduğu tarihin tespitinde iki önemli ipucunu barındırmaktadır. Birincisi, müşâherehorân denilen aylıklı zümreler içerisinde "Cemâ‘at-i Müteferrika" başlığı altında meşhur Türk denizcisi Kemal Reis’in adının geçmesidir. Kendisine 1495 yılında II. Bayezid tarafindan maaş bağlandığı bilgisi (İdris Bostan, "Kemal Reis", TDVİA, C 25, Ankara 2002, s. 226), bu defterin 1495 yılı sonrasında tutulduğunu netleştirmektedir. İkincisi de yine aynı başlık altında yer alan "Emîn-i binâ-i imâret-i cedîd" kaydıdır ("imâret” kelimesi ve altındaki satır Barkan'ın neşrinde atlanmıştır). Bu kayıt Sultan II. Bayezid'in İstanbul'da yaptırdığı Bayezid Camii ve imaretiyle alâkalıdır. İnşaat 906 yılı Zilhicce ayı sonlarında (Temmuz 1501) başlamış, Cemâziyelevvel 911 (Ekim 1505)'de tamamlanmışır (Semavi Eyice, "Beyazıt II. Camii ve Külliyesi”, TDVİA, C 6, İstanbul 1992, s. 45). İmaretin bina emini ise Hüsam Beğ bin Cendere olup, bu görevinin ardından 1506 yılında Amasya'daki İmâret-i Cedîd mütevelliliğine atanmıştır (İlhan Gök, Atatürk Kitaplı̆̆ M.C. 0.71 Numaralı 909-933/1503-1527 Tarihli İn âmât Defteri (Transkripsiyon-Değerlendirme), Marmara Üniversitesi Türkiyat Araştırmaları Enstitüsü Yayımlanmamış Doktora Tezi, İstanbul 2014, s. 395, 413, 535). Bu bilgi de defterdeki kayıtların 907-910 (1501-1505) yılları arasındaki dört yıldan birine ait olduğunu göstermektedir. 
gözden geçirilmiş ve ilgili başlık, neşrindeki bazı hatalar ${ }^{25}$ düzeltilmek suretiyle tablolaştırılarak aşağıda yeniden verilmiştir.

Tablo 2: Ehl-i Hiref Sinıfları ve Sayıları [1501-1505]

\begin{tabular}{|c|c|c|c|c|c|c|c|}
\hline \multicolumn{8}{|c|}{$\begin{array}{c}\text { Gemâ'at-i Erbâb-1 Sanâyi' ve Ehl-i Hiref } \\
\text { Üç yüz altmış neferdir }\end{array}$} \\
\hline \multicolumn{4}{|c|}{$\begin{array}{c}\text { Fî Şehr } \\
\text { 63.528 Akçe }\end{array}$} & \multicolumn{4}{|c|}{$\begin{array}{c}\text { Fî Sene } \\
762.336 \text { Akçe } \\
\end{array}$} \\
\hline \multicolumn{8}{|c|}{ Minhâ } \\
\hline & Nefer & $\begin{array}{c}\text { Fî Şehr } \\
\text { (Akçe) }\end{array}$ & $\begin{array}{l}\text { Fî Sene } \\
\text { (Akçe) }\end{array}$ & & $\begin{array}{l}\text { Ne- } \\
\text { fer }\end{array}$ & $\begin{array}{l}\text { Fî Şehr } \\
\text { (Akçe) }\end{array}$ & $\begin{array}{c}\text { Fî̀ } \\
\text { Sene } \\
\text { (Akçe) } \\
\end{array}$ \\
\hline $\begin{array}{l}\text { Şimşîrgerân } \\
\text { ma‘a şâkirdâneş }\end{array}$ & 19 & 3.041 & 36.492 & Naklbendân & 4 & 1.649 & 19.788 \\
\hline $\begin{array}{l}\text { Kemângerân } \\
\text { ma'a şâkirdâneş }\end{array}$ & 44 & 7.436 & 89.232 & $\begin{array}{l}\text { Kālîçebâfân } \\
\text { ma'a } \\
\text { şâkirdâneş }\end{array}$ & 18 & 2.288 & 27.456 \\
\hline $\begin{array}{l}\text { Tîrgerân } \\
\text { ma'a şâkîrdâneş }\end{array}$ & 20 & 3.039 & 36.468 & $\begin{array}{l}\text { Kazzâzân } \\
\text { ma'a } \\
\text { şâkirdâneş }\end{array}$ & 7 & 1.328 & 15.936 \\
\hline $\begin{array}{l}\text { Kârdgerân } \\
\text { ma'a şâkirdâneş }\end{array}$ & 7 & 1.239 & 14.868 & $\begin{array}{l}\text { Habbâzîn } \\
\text { ma'a } \\
\text { şâkirdâneş }\end{array}$ & 11 & 960 & 11.520 \\
\hline Sipergerân & 2 & 236 & 2.832 & Cerrâhîn & 4 & 1.387 & 16.644 \\
\hline $\begin{array}{l}\text { Kûftegerân } \\
\text { ma'a şâkirdâneş }\end{array}$ & 8 & 914 & 10.968 & Aşşâbân & 4 & 531 & 6.372 \\
\hline Zernişâniyân & 2 & 619 & 7.428 & Serrâcîn & 4 & 1.090 & 13.080 \\
\hline $\begin{array}{l}\text { Kuyumclyân } \\
\text { ma'a şâkirdâneş }\end{array}$ & 35 & 5.710 & 68.520 & Kündekâriyân & 3 & 590 & 7.080 \\
\hline $\begin{array}{l}\text { Külâhdûzân } \\
\text { ma'a şâkirdâneş }\end{array}$ & 19 & 3.511 & 42.132 & Zihgîrî & 3 & 414 & 4.968 \\
\hline
\end{tabular}

25 Belgedeki "Cemâ‘at-i Erbâb-1 Sanâyi' ve Ehl-i Hiref" başlığı Barkan'ın neşrinde yanlış yerde kullanıldığından, şimşîrgerân ve kemângerân sınıfları teşkilat dışında görünmektedir. Ayrıca, kûftegerân sınıfı "girift-gerân" şeklinde okunmuş, külâhdûzân ve sâztrâsân sinıflarına verilen yıllık maaş tutarları da hatalı girilmiştir. 


\begin{tabular}{|c|c|c|c|c|c|c|c|}
\hline $\begin{array}{l}\text { Postîndûzân } \\
\text { ma'a şâkirdâneş }\end{array}$ & 10 & 1.946 & 23.352 & $\begin{array}{l}\text { Sühengerân } \\
\text { ma'a } \\
\text { şâkirdâneş }\end{array}$ & 3 & 619 & 7.428 \\
\hline $\begin{array}{l}\text { Mûzedûzân } \\
\text { ma'a şâkirdâneş }\end{array}$ & 8 & 1.505 & 18.060 & $\begin{array}{l}\text { Niyâmgerân } \\
\text { ma'a } \\
\text { şâkirdâneş }\end{array}$ & 4 & 385 & 4.620 \\
\hline $\begin{array}{l}\text { Yâr Ahmed ve } \\
\text { Sinan, } \\
\text { Hayyâtân }\end{array}$ & 2 & 885 & 10.620 & Sâztrâşân & 4 & 1.268 & 15.216 \\
\hline Çahşîrciyân & 2 & 413 & 4.956 & $\begin{array}{l}\text { Anberîne- } \\
\text { ciyân }\end{array}$ & 4 & 412 & 4.944 \\
\hline $\begin{array}{l}\text { Âhengerân } \\
\text { ma'a şâkirdâneş }\end{array}$ & 13 & 1.374 & 16.488 & Zencîrbâfân & 2 & 502 & 6.024 \\
\hline \begin{tabular}{|l} 
Çilingirân \\
ma'a şâkirdâneş
\end{tabular} & 10 & 1.418 & 17.016 & \begin{tabular}{|l} 
Hacı Yusuf \\
Erreger \\
\end{tabular} & 1 & 147 & 1.764 \\
\hline $\begin{array}{l}\text { Bozdoğâniyân } \\
\text { ma'a şâkirdâneş }\end{array}$ & 7 & 930 & 11.160 & $\begin{array}{l}\text { Mahmud } \\
\text { Hakkâk }\end{array}$ & 1 & 236 & 2.832 \\
\hline $\begin{array}{l}\text { Topçuyân-1 } \\
\text { top-1 âhen } \\
\text { ve gebrân-1 } \\
\text { topçu ma'a } \\
\text { şâkirdâneş }\end{array}$ & 15 & 1.949 & 23.388 & $\begin{array}{l}\text { Baba } \\
\text { Tenterânî } \\
\text { Meşáledâr }\end{array}$ & 1 & 354 & 4.248 \\
\hline Tüfenkçiyân & 2 & 442 & 5.304 & $\begin{array}{l}\text { Hacı İbrahim } \\
\text { Helvaŷ́ }\end{array}$ & 1 & 295 & 3.540 \\
\hline $\begin{array}{l}\text { Kazgânyân } \\
\text { máa şâkirdâneş }\end{array}$ & 22 & 3.795 & 45.540 & $\begin{array}{l}\text { Yunus } \\
\text { Mârî }\end{array}$ & 1 & 295 & 3.540 \\
\hline $\begin{array}{l}\text { Mücellidân } \\
\text { ma'a şâkirdâneş }\end{array}$ & 9 & 1.887 & 22.644 & $\begin{array}{l}\text { Şeyh Ali } \\
\text { Haymedûz }\end{array}$ & 1 & 236 & 2.832 \\
\hline $\begin{array}{l}\text { Nakkāşân } \\
\text { ma'a şâkirdâneş }\end{array}$ & 22 & 5.958 & 71.496 & $\begin{array}{l}\operatorname{Hac1}() \\
\text { Zerduz }\end{array}$ & 1 & 295 & 3.540 \\
\hline
\end{tabular}

Devletin maaşlı çalı̧sanları arasında yer alan Ehl-i hiref mensuplarına dair en ayrıntılı bilgiler mufassal maaş defterlerinde bulunmakla birlikte, üç aylık ya da yıllık tutulan maaş icmal defterleri de sayılar ve ödenen toplu ücretler bakımından önemli veriler içermektedir. 907-910 (1501-1505) yılları arasındaki dört yıl- 
dan birine ait olan yukarıdaki belge ile 1526 tarihli maaş defteri arasındaki 20-25 yıllık boşluğu dolduranlar da bu defterlerdir. İçlerinde en erken tarihlilerinden biri, II. Bayezid'in vefatı öncesine ait Şevval-Zilhicce 917 (22 Aralık 1511-18 Mart 1512) tarihli üç aylık mevâcib defteridir. Buradaki kayıtta Ehl-i hiref ile müşâherehorân cemaati toplamı 897 kişi olarak verilmiştir. ${ }^{26}$ Bu verinin çözümlenmesi iki yıl sonrasına ait kayıtlarla mümkün olabilmektedir. Sultan I. Selim'in Çaldıran Zaferi öncesine ait Rebî́ülâhir-Cemâziyelâhir 920 (26 Mayıs-21 Ağustos 1514) tarihli defterde Ehl-i hiref sayısı 326, müşâherehorân sayıs1 597, ikisinin toplamı ise 923 'tür. ${ }^{27}$ Bu bilgi, Sultan II. Bayezid'in vefatında Ehl-i hiref mevcudunun yine 325 civarında olduğunu göstermektedir.

Üç aylık mevâcib defterlerinde kayıtlı verilerden tertip edilmiş aşağıdaki tabloda görüleceği üzere, 1514 yılı sonrası geçen altı yılda kurum bünyesindeki sanatkâr sayısı 100 kişi (\%30) artmış ve Yavuz'un vefat ettiği 1520 yılı sonunda 425'e ulaşmışt. Sultan Süleyman'ın tahta çıkışılla birlikte bir yll içerisinde bu sayıya 121 kişi daha ilave oldu ve toplam mevcut 546’yı buldu. Bu hızlı artışta, şehzadeliğinde kapı halkı arasında olan sanatkârların Sultanla birlikte İstanbul'a getirilerek Ehl-i hiref kadrosuna dâhil edilmesinin de payı vardı. 1526 kayıtlarına göre bu şekilde gelenlerin sayısı otuzdu. Şubat-Mayıs 1523 ve 1524 yılındaki alımlarla birlikte teşkilata bağlı sanatkâr sayısı 612'ye, ödenen yıllık maaş tutarı da yaklaşık 1,5 milyon akçeye ulaştı. belgede ise Ehl-i hiref mevcudu 308 olarak kayıtlıdır. Bu sayıya, aynı evrakta "Ehl-i hiref ustaları" başlığı altında verilen 21 rakamı da ilave edildiğinde toplam mevcut 329'a ulaşmaktadır. Kanunî dönemi maaş defterlerinde Ehl-i hiref bünyesinde bulunan cerrahlar, bu tarihte 42 kişi ile kurum dışında yer almaktadır (BOA, TSMA, E.745/64 (E.5475). Yayımlanan bu evrak için bk. Barkan, agm., s. 312-313). 
Tablo 3: Ehl-i Hiref Sayıları (1514-1530)

\begin{tabular}{|c|c|c|c|}
\hline Tarih & $\begin{array}{c}\text { Cemâ'at-i } \\
\text { Ehl-i Hiref } \\
\text { (Nefer) }\end{array}$ & $\begin{array}{c}\text { Fî Yevm } \\
\text { (Akçe) }\end{array}$ & $\begin{array}{c}\text { Fî Sene } \\
(\text { Akçe })\end{array}$ \\
\hline 26 Mayıs-21 Ağustos $1514^{28}$ & 326 & 1.998 & - \\
\hline 14 Eylül-11 Aralık $1520^{29}$ & 425 & 2.483 & - \\
\hline 7 Haziran-30 Kasım $1521^{30}$ & 546 & 3.743 & 1.336 .790 \\
\hline 20 Kasim 1522-16 Şubat $1523^{31}$ & 523 & 3.719 & 1.315 .826 \\
\hline 16 Mayıs-12 Ağustos $1523^{32}$ & 570 & 4.093 & 1.437 .682 \\
\hline 10 Kasım 1523-6 Şubat $1524^{33}$ & 562 & 4.028 & 1.425 .912 \\
\hline 29 Ekim 1524-25 Ocak $1525^{34}$ & 612 & 4.100 & 1.453 .529 \\
\hline 29 Mayıs-24 Ağustos $1530^{35}$ & 601 & 4.091 & 1.433 .619 \\
\hline
\end{tabular}

Çalışmamızın ana kaynakları arasında bulunan Kanunî dönemine ait dört adet Ehl-i hiref maaş defterinden 1526 tarihli ilk deftere göre, kuruma bağlı 38 sanat sınıfina mensup sanatkâr sayısı 598'dir. Bu da 1514 yılı sonrası geçen 12 yılda teşkilattaki sanatçı istihdamının \%85 oranında arttığını ortaya koymaktadır. Bu sayı, 1545 tarihli ikinci defterde 779'a yükselmiş, 1557-58 tarihli üçüncü defterde 597, 1566 tarihli dördüncü defterde ise 639 olmuştur. Aşağıdaki tablo ise Sultan II. Bayezid ve I. Süleyman devri kayıtlarından hareketle 1501-1505 ve 1526 yillarında Ehl-i hiref çatısı altında yer alan sanat sınıflarını ve sayılarında yaşanan değişimi göstermektedir.

BOA, MAD.d. 23, vr. 24a (Rebî‘ülâhir-Cemâziyelâhir 920).

BOA, MAD.d. 23, vr. 9a (Şevval-Zilhicce 926).

BOA, MAD.d. 23, vr. 16b, 18a (Receb-Zilhicce 927).

BOA, MAD.d.. 23, vr. 14a (Muharrem-Rebî'ülevvel 929).

BOA, MAD.d. 23, vr. 34b (Receb-Ramazan 929).

BOA, MAD.d. 23, vr. 10a (Muharrem-Rebî'ülevvel 930).

BOA, MAD.d. 23, vr. 5a (Muharrem-Rebî‘ülevvel 931).

BOA, MAD.d. 23, vr. 27b (Şevval-Zilhicce 936). 
Tablo 4: Ehl-i Hiref Sinıfları ve Sayıları (1501-1505, 1526)

\begin{tabular}{|c|c|c|c|c|c|}
\hline \multirow{2}{*}{ Sinifi } & \multicolumn{2}{|c|}{ Sayısı } & \multirow{2}{*}{ Sinifi } & \multicolumn{2}{|l|}{ Sayıs } \\
\hline & {$[1501-1505]$} & 1526 & & [1501-1505] & 1526 \\
\hline Nakkāşân & 22 & 41 & Neccârân & - & 9 \\
\hline Mücellidân & 9 & 8 & Harrâtîn & - & 10 \\
\hline Külâhdûzân & 19 & 25 & Mûzedûzân & 8 & 13 \\
\hline Zergerân & 35 & 58 & Abâyîbâfân & - & 8 \\
\hline Sîmkeşân & - & 4 & Kemhâbâfân & - & 21 \\
\hline Hakkâkîn & 1 & 9 & Kālîçebâfân & 18 & 16 \\
\hline Zerdûzân & 1 & 5 & Câmeşûyân & - & 16 \\
\hline Kazzâzân & 7 & 15 & Destvâneî & - & 3 \\
\hline Postîndûzân & 10 & 14 & Kâşigerân & - & 11 \\
\hline Zernişânî & 2 & 22 & Küştigîrân & - & 7 \\
\hline Kûftegerân & 8 & 5 & Cerrâhîn & 4 & 50 \\
\hline Anberîneî & 4 & 3 & $\begin{array}{l}\text { Müteferrika-i } \\
\text { Ehl-i Hiref }\end{array}$ & - & 8 \\
\hline Kündekârân & 3 & 14 & Serrâcîn & 4 & 4 \\
\hline Şimşîrgerân & 19 & 18 & Zencîrbâfân & 2 & 1 \\
\hline $\begin{array}{l}\text { Kârdgerân ile } \\
\text { Sühengerân vd. }\end{array}$ & 10 & 18 & Helvayî & 1 & 1 \\
\hline Niyâmgerân & 4 & 7 & Haymedûz & 1 & 2 \\
\hline Siperdûzân & 2 & 8 & Hayyâtân & 2 & - \\
\hline Bozdoğânî & 7 & 17 & Çahşîrciyân & 2 & - \\
\hline Tîrgerân & 20 & 15 & Âhengerân & 13 & - \\
\hline Kemângerân & 44 & 23 & Naklbendân & 4 & - \\
\hline Çilingirân & 10 & 20 & Habbâzîn & 11 & - \\
\hline Kazgānyân & 22 & 18 & Aşşâbân & 4 & - \\
\hline Topçuyân-1 Âhen & 15 & 8 & Zihgîrî & 3 & - \\
\hline Tüfekçiyân & 2 & 10 & Erreger & 1 & - \\
\hline Dimeşkīgerân & - & 22 & Meşaledâr & 1 & - \\
\hline Sâztrâşân & 4 & 11 & Mârî & 1 & - \\
\hline Toplam & 280 & 418 & Toplam & 80 & 180 \\
\hline
\end{tabular}


Kanunî dönemine ait olup maaş defteri niteliği taşımayan, ancak içerdiği bilgi oldukça kıymetli olan bir diğer kaynak da 1564 tarihli Ehl-i hiref yoklama defteridir. Defterde, hayatta olan teşkilat mensupları güncel maaş defterinden, vefat etmiş olanlar ise geçmiş yıllara ait defterlerden kontrol edilip kaydedilmiştir. Elde edilen sonuçlar defterin ilk sayfasında özetlenmiş, 438 kişinin hayatta 601 kişinin de vefat etmiş olduğu bilgisi verilmiştir. Bu defterin önemi, farklı sanat sınıflarına mensup sanatkârların "zinde" ve "müteveffa" başlıkları altında isim isim kaydedilmiş olmasıdır. Bu da biz araştırmacılara 1526, 1545 ve 1557-58 tarihli maaş defterlerindeki verilerden hareketle, 1564 yılından önce ölmüş sanatçılar için bir vefat tarih aralığı verme imkânı sağlamaktadır. Tutulan bu defter için yapılan taramalarda geriye doğru hangi tarihe kadar gidildiğini yani bakılan en eski defterin tarihini netleştirmek mümkün olmamıştır. Ancak, defterde yer almayan Tebrizli sanatkârlardan Nakkaş Hoca Beğ ve Kuyumcu Yâdigâr'ın Ocak 1532'de hayatta oldukları bilgisi ${ }^{36}$, en azından bu tarihe kadar inilmediğini göstermektedir. 1545 yılı öncesi vefat etmiş sanatkârların ölüm tarihlerine dair farklı kaynaklardan elde edilecek yeni bilgiler, geçmişe yönelik 25-30 yıllık bir taramayla hazırlandığını düşündüğümüz bu defterin başlangıç noktasını tespit etmeyi kolaylaştıracaktır.

\section{Tebrizli Sanatkârlar (1526-1566)}

1526 tarihli Ehl-i hiref teftiş defteri, kayıtlı 598 sanatkârın hangi padişah döneminde teşkilata dâhil olduklarına dair önemli bilgiler içermektedir. Buna göre; sanatkârların 7'si Sultan II. Mehmed, 111'i II. Bayezid, 215’i I. Selim, 265’i ise I. Süleyman devrinde deftere kaydedilmiştir. Çıkan sonuç, Sultan Süleyman'ın tahta çıkışından itibaren altı yıl içerisinde kurum bünyesinde ciddi sayıda sanatçı istihdam edildiğini göstermektedir. Bu artışın sonraki yirmi yılda da sürdüğü 1545'te sayının 779'a yükselmesinden anlaşılmaktadır. Öte yandan, söz konusu defterde kayıtlı Tebrizli sanatkâr sayısının da 58 olduğu görülmektedir. Bunlardan 5’inin Sultan II. Bayezid, 16'sının I. Selim, 37'sinin de I. Süleyman devrinde Ehl-i hiref kadrosuna alındıkları tespit edilmiştir.

1526 teftişi, bu dönem sanatçı istihdamında İstanbul ve Edirne Harc-1 Hassa Eminliklerinin ${ }^{37}$ de etkin rol üstlendiğini ortaya koymaktadır. 598 sanatçıdan

36 BOA, Kâmil Kepeci Tasnifi (KK.d.), 1764, s. 158.

37 İstanbul, Galata, Gelibolu, Edirne ve Bursa gibi şehirlerde Harc-ı hassa eminleri vardı. Bu eminler sarayların ve saraylıların yiyecek ve giyecek giderlerini, aylıklarını, saray için çalışan bazı meslek sahiplerinin ücretlerini, emeklilerin emekli maaşlarını, giderleri Hazinece karşlanan cami ve mescitlerdeki görevlilerin maaşlarını öderdi (Halil Sahillioğlu, "Emîn”, TDVİA, C 11, İstanbul 
58’inin $(\% 9,7)$ kuruma atanmadan önce maaşlarını buralardan aldıkları bilgisi, Osmanlı sarayında Ehl-i hiref kadrosunda bulunmayan başka sanatçların varlı̆̆ına delil teşkil etmektedir. Kanûnî öncesi saray hizmetine alınan bu 58 kişinin 50'sine İstanbul, 8’ine Edirne Harc-1 Hassa Eminliğinden maaş bağlandı̆̆ı görülmektedir. İçlerinde Tebrizli olup olmadığı araştırıldığında ise karşımıza Yavuz’un 1514 Çaldıran Zaferi sonrası Amasya üzerinden İstanbul'a getirttiği sanatkârlar çıkmaktadır. Listeler incelendiğinde, haklarında o dönem Tebriz'den sürgün geldikleri şeklinde açıklama yapılan sanatçı sayısının 35 olduğu, bunlardan 23’ünün Ehl-i hiref kadrosuna alınmadan önce İstanbul (18 kişi) ve Edirne (5 kişi) Hassa Harcı'ndan maaş bağlanarak sarayda istihdam edildikleri tespit edilmiştir. Örneğin, içlerinde meşhur Şah Kulu'nun da bulunduğu yedi nakkaşın Ehl-i hirefe dâhil edilmeden önce İstanbul Hassa Harcı'ndan maaş aldıkları bilgisi kayıtlarda yer almaktadir.

1515 yılında İstanbul'a getirilen Tebrizli sanatkârların sayısı hakkında ise net bir bilgiye sahip değiliz. Ancak önemli bir kısmına saray hizmetine girer girmez Ehl-i hiref kadrosu tahsis edilmediğini biliyoruz. Bu konudaki mühim belgelerden biri de Topkapı Sarayı Müzesi Arşivi'nde kayıtlı 9784 numaralı defterdir. Tek varaklık, tarihsiz bu defterde Tebriz'den getirilen bir grup sanatkârın listesi yer almaktadır. İçlerinde Zerger Derviş Muhammed gibi 1526 kayıtlarında Tebriz'den sürgün geldiği belirtilen sanatçıların bulunması, belgenin 1515 tarihli olduğunu kanıtlamaktadır. Aşağıda tablo haline getirilmiş listede 16 nakkaş, farklı dallardan 18 sanatkâr ve 4 de sâzende olmak üzere 38 kişinin ismi yazılıdır. Ayrıca yanlarında 23 kişiden ibaret sanatlarında ustalaşmış oğulları bulunmaktadır ${ }^{38}$.

Tablo 5: Tebriz'den Getirilen Bir Grup Sanatkârın Listesi (1515)

\begin{tabular}{|c|c|c|c|}
\hline \multicolumn{4}{|c|}{ Tafsîl-i esâmî-i üstâdân ki Tebriz'den gelmişlerdir. } \\
\hline \multicolumn{4}{|c|}{ Cemấat-i Nakkāsâân-ı berîn-i mûcib } \\
\hline $\begin{array}{c}\text { Şah Muhammed } \\
\text { Musavvir }\end{array}$ & $\begin{array}{l}\text { Abdülganî } \\
\text { Musavvir }\end{array}$ & $\begin{array}{l}\text { Derviş Beğ } \\
\text { Musavvir }\end{array}$ & $\begin{array}{l}\text { Şeyhhan } \\
\text { Nakkāss }\end{array}$ \\
\hline $\begin{array}{l}\text { Alâeddin Muhammed } \\
\qquad \text { Nakkāş }\end{array}$ & $\begin{array}{c}\text { Mansur Beğ } \\
\text { Nakkāşs }\end{array}$ & $\begin{array}{c}\text { Şeyh Kemal } \\
\text { Nakkāş }\end{array}$ & $\begin{array}{l}\text { Ali Beğ } \\
\text { Nakkāşs }\end{array}$ \\
\hline $\begin{array}{l}\text { Ahî Beğ } \\
\text { Nakkāşs }\end{array}$ & $\begin{array}{l}\text { Abdülhâlık } \\
\text { Nakkāşs }\end{array}$ & $\begin{array}{l}\text { Mirza Beğ } \\
\text { Nakkāşs }\end{array}$ & $\begin{array}{l}\text { Nazar } \\
\text { Nakkāşs }\end{array}$ \\
\hline
\end{tabular}

1995, s. 112; Arif Bilgin, "Harc-1 Hâssa Emini”, TDVIA, C Ek-1, İstanbul 2016, s. 535-536).

38 BOA, TSMA. D.9784; İ. H. Uzunçarşıll, agm., s. 24.

Belleten, Aralık 2021, Cilt: 85/Sayı: 304; 849-887 
Ehl-i Hiref Maaş Defterlerinde Kayıtlı Tebrizli Sanatkârlar

\begin{tabular}{|c|c|c|c|}
\hline $\begin{array}{l}\text { Abdülfettah } \\
\text { Nakkāş }\end{array}$ & $\begin{array}{l}\text { Mîr Aga } \\
\text { Nakkāş }\end{array}$ & $\begin{array}{l}\text { Şeref } \\
\mathcal{N} a k k \bar{a} s \\
\end{array}$ & $\begin{array}{l}\text { Ali Kulu } \\
\text { Nakkāş }\end{array}$ \\
\hline \multicolumn{4}{|l|}{ Yekûn 16 nefer } \\
\hline \multicolumn{4}{|c|}{ Cemâ'at-i Müteferrika } \\
\hline $\begin{array}{l}\text { Sultan Ali } \\
\text { Hakkâk }\end{array}$ & $\begin{array}{l}\text { Abdülvâhid } \\
\text { Kâtip }\end{array}$ & $\begin{array}{l}\text { Sultan Ali } \\
\text { Kâtip } \\
\end{array}$ & $\begin{array}{c}\text { Arîzî Muynî } \\
\text { Dûzz }\end{array}$ \\
\hline $\begin{array}{c}\text { Mevlânâ Kelâmî } \\
\text { Kazzâaz }\end{array}$ & $\begin{array}{c}\text { Hoca Gelen } \\
\text { Zerger }\end{array}$ & $\begin{array}{c}\text { Sultan Kulu } \\
\text { Zerger }\end{array}$ & $\begin{array}{l}\text { Derviş Muhammed } \\
\text { Zerger }\end{array}$ \\
\hline $\begin{array}{c}\text { Mîr Hüseyin } \\
\text { Kûfteci }\end{array}$ & $\begin{array}{l}\text { Emînüddin } \\
\text { Kûfteci }\end{array}$ & $\begin{array}{l}\text { Hâcegî } \\
\text { Misger }\end{array}$ & $\begin{array}{c}\text { Abdürrezzâk } \\
\text { Kâş̧ıิtraş }\end{array}$ \\
\hline $\begin{array}{l}\text { Burhan } \\
\text { Kâş̧ิ-traş }\end{array}$ & $\begin{array}{c}\text { Mahmud } \\
\text { Kālcı }\end{array}$ & $\begin{array}{c}\text { Hacı Muhammed } \\
\text { Camcı }\end{array}$ & $\begin{array}{c}\text { Muhammed Can } \\
\text { Camcr }\end{array}$ \\
\hline $\begin{array}{c}\text { Koç Ahmed } \\
\text { Hallaç }\end{array}$ & $\begin{array}{c}\text { Muhammed } \\
\text { Zihgîrci }\end{array}$ & & \\
\hline \multicolumn{4}{|l|}{ Yekûn 18 nefer } \\
\hline \multicolumn{4}{|c|}{ Cemấat-i Sâzendegân } \\
\hline $\begin{array}{c}\text { Şeyh Murad } \\
\text { Naycı }\end{array}$ & $\begin{array}{c}\text { Imam Kulu } \\
\text { Nayzen }\end{array}$ & $\begin{array}{c}\text { Şah Murad } \\
\text { Kānuncu }\end{array}$ & $\begin{array}{c}\text { Maksud } \\
\text { Dâireci } \\
\end{array}$ \\
\hline \multicolumn{4}{|l|}{ Yekûn 4 nefer } \\
\hline \multicolumn{4}{|c|}{ Cemªn 38} \\
\hline gayrı yi & fer oğull & dır. Anlar dahi & lardır. \\
\hline
\end{tabular}

Toplam 61 kişiden oluşan bu sanatçı topluluğu içinde isimleri yazılı 38 kişiyi 1526 tarihli Ehl-i hiref defterinde aradığımızda karşımıza sadece üç kişinin adı çıkmaktadır. Bunlar; kuyumcular sınıfından Derviş Muhammed, Hoca Gelen/Hoş Gelen ve Sultan Kulu adlı sanatçlardır. Kalan 35 kişiden 10’unun izine ise 1545 tarihli defterde rastlanmaktadır. Bunların yedisi nakkaşlardan olup isimleri; Şah Muhammed, Ali Beğ, Ahî Beğ, Abdülhâlık, Abdülfettah, Mîr Aga/Emir Ağa ve Ali Kulu'dur. Diğgerleri de Kâtip Abdülvâhid, Misger Hâcegî ve Camcı Hacı Muhammed'dir. Üç sanatçının adı ise 1564 yllı itibariyle Ehl-i hiref mensuplarından hayatta olan ve olmayanların listesinin çıkartıldığı yoklama defterinde bulunmaktadır. 1526 sonrası kuruma alınıp 1545 öncesi vefat eden bu üç isim Hakkâk Sultan Ali, Kûfteci Mîr Hüseyin ve Kâtip Sultan Ali'dir. Geriye kalan 22 kişinin akıbetine dair elimizdeki defterlerde bir kayda rastlanmamıştır. Elde edilen tüm bu bilgiler Sultan Bayezid, Selim ve Süleyman devrinde saray hizmetine girmişs sanatkârların 
tamamının Ehl-i hiref kadrolarında yer almadığını, Tebriz'den getirilenlerin büyük bir kısmının da uzun süre İstanbul ve Edirne Hassa Harcı'ndan maaş bağlanmak suretiyle sarayda çalıştırıldıklarını göstermektedir.

Incelemelerimiz neticesinde tespit edebildiğimiz, günümüze ulaşan en erken tarihli Ehl-i hiref maaş defterlerinde kayıtlı Tebrizli sanatkâr sayısı 90'dır. Dört maaş bir de yoklama defterinden çıkartılan bu sayı içerisinde 1526 kayıtlarında yer alanlar çoğunluğu teşkil etmektedir. Daha önce de belirtildiği üzere, bu tarihteki Ehl-i hiref mevcudunun 58 kişi ile yaklaşık \%10'unu oluşturan Tebrizli sanatkâr sayısı 1545 'te 46 'ya $(\% 5,9)$ inmiş, 1557-58 tarihinde yarıdan fazla azalarak 22'ye $(\% 3,7)$ gerilemiş, 1566'da ise 15 'e $(\% 2,3)$ düşmüştür. Vefatlardan kaynaklı bu eksi yöndeki gidişat sonraki yıllarda da devam etmiştir. 1526 ve 1545 verileri, Tebrizli sanatkârların Ehl-i hiref kadrolarında en yüksek sayıya 1530'lu yılların başında ulaştığını göstermektedir. Maaş defterlerine peyderpey kaydedilen bu sanatkârlar arasında çoğunluğu oluşturanlar ise nakkaşlar ${ }^{39}$ ile kuyumculardı. Sayılarındaki artışın bir sonucu olarak 1526 yılı sonrasında bu sanat sınıflarına ait kadrolar ikiye bölündü. 1545 kayıtlarında görüldüğü üzere, nakkaşlar ve kuyumcular arasında Anadolu ve Rumeli kökenliler için Bölük-i Rûmiyân, Tebriz kökenliler için de Bölük-i Acemân teşkil edildi. Bu iki ayrı bölük uygulamasına ancak Tebrizli sanatkâr sayısının vefatlar nedeniyle giderek azaldığı Kanunî dönemi sonrasında son verildi ${ }^{40}$.

Tablo 6: Tebrizli Sanatkârların Sanat Sınıfları ve Sayıları (1526-1566)

\begin{tabular}{|l|c|l|c|}
\hline \multicolumn{1}{|c|}{ Sinıfi } & Sayısı & \multicolumn{1}{c|}{ Sinıfi } & Sayısı \\
\hline Nakkāşân & 25 & Kazgānyân & 2 \\
\hline Zergerân & 18 & Kâşîgerân & 1 \\
\hline Zernişânî & 9 & Postîndûzân & 1 \\
\hline Kûftegerân & 2 & Abâyîbâfân & 3 \\
\hline Hakkâkîn & 3 & Külâhdûzân & 1 \\
\hline Sîmkeşân & 2 & Mücellidân & 1 \\
\hline Zerdûzân & 2 & Kâtibân-1 Kütüb & 4 \\
\hline
\end{tabular}

39 Türk nakış tarihi ile ilgili Rıfkı Melûl Meriç’in 1953 yılında Osmanlı arşiv belgelerine dayalı yaptığı çalışması günümüzde hâlâ bir başvuru eseri olma konumunu muhafaza etmektedir. Bk. Rıfkı Melûl Meriç, Türk Nakış San ́atı Tarihi Araştırmalan 1 Vesikalar, Ankara 1953. Nakkaşlarla ilgili yapılan bir diğer çalışma için de bk. Murat Uluskan, "İstanbul'un Yapı Sanatkârları: Nakkaşlar ve Sıvacılar (1700-1838), Türk Kültürü Incelemeleri Dergisi, S. 28 (İstanbul 2013), s. 11-50.

BOA, TSMA. D.9613/1, vr. 2b-3b (Mart-Mayıs 1596).

Belleten, Aralık 2021, Cilt: 85/Sayı: 304; 849-887 


\begin{tabular}{|l|c|l|c|}
\hline Şimşîrgerân & 2 & Cerrâhîn & 1 \\
\hline Siperdûzân & 5 & Küştigîrân & 3 \\
\hline Kârdgerân ile Sühengerân vd. & 2 & $\begin{array}{l}\text { Müteferrika-i } \\
\text { Ehl-i Hiref }\end{array}$ & 3 \\
\hline \multicolumn{2}{|c|}{ Toplam: 90 }
\end{tabular}

Söz konusu kırk bir yıllık dönemde, isimlerini tespit ederek ekte tablolar halinde verdiğimiz yirmi sanat sınıfina mensup 90 sanatçının 25’i (\%28) nakkaşlardan oluşmaktadır. İçlerinde, Sultan II. Bayezid devrinde Ehl-i hirefe dâhil edilip 1526 yılı itibariyle hayatta olan beş sanatçı vardır. Bunlar; Hasan bin Muhammed, Ressâm Hasan bin Abdülcelil, Melek Ahmed ve oğulları Muhammed ile Ali'dir. Hasan bin Muhammed'in, II. Bayezid'in saltanatının ilk on yılında yani 1481-1490 yılları arasında saray hizmetine girdiği hakkındaki açıklamada yer almaktadır. Keza, Yavuz Sultan Selim’in Tebriz'deki Safevî sarayından getirttiği Ressâm Şah Kulu'nun Bağdatlı olduğu da 1545 tarihli maaş defterinde yazılıdır. 1515-1566 yılları arasında hayatta olup en az 51 yıl saray hizmetinde bulundukları anlaşılan dört Tebrizli nakkaşın isimleri ise Şah Muhammed, Ahî Beğg, Ali Kulu ve Emir A ğa’dır.

Ehl-i hiref kadrolarında Tebrizli ikinci kalabalık grup 18 sanatçı (\%20) ile zergerân yani kuyumculardır. 1526'da günlük 26 akçe ile en yüksek maaşı alan Hoca Mircan’ın Muzaffer, Ahmed, Muhammed ve Mustafa; Maksud Ali'nin de Derviş ve Burhan adlı oğullarının olduğu ve aynı sınıf içerisinde yer aldıkları bu defterlerde kayıtlıdır. 1526-1566 yılları arasında hayatta olan iki kuyumcu ise Muzaffer bin Mircan ve Şah Hüseyin bin Şah Hasan adlı sanatçılardır. Kuyumculardan sonra sıralamada üçüncü sırayı 9 kişi (\%10) ile zernişân̂̂ denilen altın kakmacılar almaktadır. Altından motifleri kakma yöntemiyle yerleştiren bu sanatkârlar arasında, 1566 yılında hayatta olup en az kırk bir yıl kurumda çalıştıkları bilinen üç isim; Hüseyin bin Cemaleddin, Mesud-ı Şirâzî ve Ayas Çerkes'dir. Ayrıca, Tebriz'den getirildikten sonra Sultan Selim zamanında vefat eden Zernişânî Kāsım’ın Muhammed ve Ali isimli iki oğlu da aynı sınıf içerisinde yer almaktadır.

Tebrizli sanatkârların 52'sinin (\%58) mensup olduğu bu üç sanatçı topluluğunun dışında kalan 38 kişi (\%42) ise on yedi sanat sınıfina dağılmıştır. İçlerinde, Zerdûz Beşâret Gürcü ve Hattât Abdülvâhid gibi yarım asrı aşkın sarayın himayesinde çalışmalarını sürdüren sanatkârlar vardır. Ayrıca, Ehl-i hirefle ilgili araştırmalarda "keştigerân" şeklinde hatalı bir okumayla saray kayıklarının yapım, onarım ve bakımından sorumlu sanatçılar olarak tanımlanan sınıfın aslında küştigîrân yani 
güreşçiler olduğu tespit edilmiştir. 1557-58 tarihli maaş defterinde Türkçe adıyla verilen bu sınıf içerisinde, Kanunî döneminde saraya alınmış Acem menşeli Kemal, Şah Kulu ve Pars adlı üç güreşçi yer almaktadır. "Müteferrika-i Ehl-i Hiref" başlı̆̆ altında farklı sanatlar icra eden az sayıdaki sanatkârın kayıtlı olduğu sınıfta ise Tebriz'den getirilmiş Hacı Pîrî ve Muhammed Ali adlı iki haymedûz (çadırcı) ve Hacı Muhammed isminde bir de camcı bulunmaktadır.

Bu sanatçlar arasında, 1526 yılı itibariyle en yüksek maaşı zernişânî sınıfından günlük 28 akçe ile İsmail bin Abdullah almaktadır. Onu 26 akçe ile Kuyumcu Hoca Mircan, 24 akçe ile Nakkaş Melek Ahmed ve 22 akçe ile Nakkaş Şah Kulu ve Hâkkâk Şirem takip etmektedir. Yevmiyesi 20 akçenin üzerinde olan diğer sanatçlar; Nakkaş Hasan bin Abdülcelil ile Hasan bin Muhammed, Kuyumcu Maksud Ali ve Zernişânî Hüseyin bin Cemaleddin'dir. 1566 yllına gelindiğinde ise kayitlı on beş Tebrizli sanatkârdan en yüksek maaşı 29,5 akçe ile Kuyumcu Şah Hüseyin bin Şah Hasan'ın, en düşük maaşı da 6,5 akçe yevmiye ile Nakkaş Ali Kulu'nun aldığı görülmektedir.

Tebrizli sanatkârlar arasında baba-oğul aynı sanat sınıfinda çalışanlar olduğunu yukarıda örnekleriyle belirtmiştik. Ancak 1526 tarihli Ehl-i hiref defterinde kayıtlı bazı sanatçıların sanatkâr babaları, isimleri belirtilmekle birlikte, vefat etmiş ya da kurum dışında hizmet ediyor olmaları nedeniyle kadrolarda yer almamaktadır. $\mathrm{Bu}$ şekilde tespit edilen sanatkâr sayısı 12 olup isimleri aşağıdaki tabloda verilmiştir. İçlerinde; Fatih zamanında İran'dan gelerek Osmanlı Sarayında kâtip olarak istihdam edilen Abdullah, II. Bayezid devrinde Osmanlı hizmetine giren Nakkaş Muhammed ve Abdülcelil, Yavuz'un saltanatında Tebriz'den getirilen ve ismi ilgili defterin neşrinde "Ş̧ehrevân" şeklinde hatalı okunan Kuyumcu Pervâne gibi sanatkârlar bulunmaktadır.

Tablo 7

\begin{tabular}{|l|l|}
\hline \multicolumn{1}{|c|}{ Sinıfi } & \multicolumn{1}{c|}{ İsmi } \\
\hline \multirow{5}{*}{ Nakkāşân } & $\begin{array}{l}\text { Hasan bin Muhammed } \\
\text { Hasan bin Abdülcelil } \\
\end{array}$ \\
& $\begin{array}{l}\text { Muhammed bin Abdurrahman } \\
\text { Şah Hüseyin bin Ressâm Hüsâm }\end{array}$ \\
\hline \multirow{2}{*}{ Zernişânî } & $\begin{array}{l}\text { Hüseyin bin Cemaleddin } \\
\text { Muhammed bin Kāsm } \\
\text { İmad Beğ bin Şemseddin Ali }\end{array}$ \\
\hline
\end{tabular}




\begin{tabular}{|l|l|}
\hline Zergerân & $\begin{array}{l}\text { Mustafa bin Pervâne } \\
\text { Şah Hüseyin bin Şah Hasan }\end{array}$ \\
\hline Şimşîrgerân & Halil bin Şeyh Hasan \\
\hline Postîndûzân & Ahmed bin Hacı Lütfullah \\
\hline Kâtibân-1 Kütüb & Abdurrahman bin Abdullah \\
\hline
\end{tabular}

\section{Sonuç}

Sanatın en önemli alıcısı ve koruyucusu olan saraylar arasında 15. yüzyıldan itibaren artan iktidar mücadeleleri ve kültürel ilişkiler sanatsal ürünlerin çeşitlenip çoğalmasına, kullanılan üslupların da farklı coğrafyalara aktarılmasına vesile teşkil etti. Yaşanan savaşların ardından fethedilen bölgelerdeki nitelikli insanlar, saray sanatkârları ve eserleri savaş ganimeti olarak yönetim merkezlerine nakledildi. Doğuda olduğu gibi batıda da görülen bu uygulamanın yanı sıra sanatçılar, başka ülkelerin hâkimleri tarafindan saraylarında çalışmaları için davet de edildiler. Kimi zaman zorunlu kimi zaman da gönüllü olarak kendilerine sunulan cazip sanat ortamlarını ve yüksek ücret tekliflerini kabul ederek, yeni sanat hamilerine hizmet etmek üzere aileleriyle birlikte göç ettiler. Ekonomik kaygılardan yoksun, ideal ortamlarda ürettikleri eserlerle sanatlarını ve üsluplarını geliştirdiler, şöhretlerini artırdılar ve yeni öğrenciler yetiştirdiler.

Osmanlı Sarayının himayesinde pek çok sanat sınıfını bünyesinde barındıran Ehl-i hiref teşkilatı, mensuplarının bir usta-çırak ilişkisi ve disiplini içinde yetiştiği, saray idaresinin talebi doğrultusunda eserler üretip sanatlarını teşhir etme firsatı bulduğu bir kültür ve sanat kurumuydu. Fatih'ten başlayarak Sultan Bayezid, Selim ve Süleyman'ın sanata ve sanatçıya verilen desteği bir devlet politikası haline getirmeleri, Ehl-i hirefin bir teşkilat çatısı altında toplanıp gelişmesine büyük katkı sağladı. Özellikle, sanatçı istihdamında \%68'lik bir artışı görüldüğü 1515-1521 yılları, Osmanlı sanatının şekillendiği ve icra edildiği kurumun da gelişimini tamamladığı bir dönemin başlangıcını oluşturdu. Kendi bünyesinde yetiştirdiği sanatkârlar dışında, sarayın enderun ve birun hizmet birimlerinden, şehzade ve vezirlerin kapı halkından, saray dışında sanatıyla öne çıkanlardan, devşirmelerden, esirlerden, hediye sunulanlardan ve yeni fethedilen topraklardan gelenler Ehl-i hiref kadrolarını nitelik ve nicelik olarak daha da zenginleştirdi. Osmanlı sultanları, yürüttükleri politikanın sonucu olarak başkentlerini bir kültür ve sanat merkezi haline getirdikleri gibi sanatçlar nezdindeki hamilik konumlarını da yücelttiler. 
Bu dönemde, kurumdaki sanatsal faaliyetlerin ve çeşitliliğin artışında Tebriz başta olmak üzere İran coğrafyasından gelen sanatçlların saray hizmetinde geniş bir şekilde yer almaya başlamalarının da önemli bir payı vardır. 1526 yılında Ehl-i hirefin yüzde onunu Tebrizlilerin oluşturması bunun somut bir göstergesidir. Kanunî dönemine ait Ehl-i hiref maaş defterleri $102(90+12)$ Tebrizli sanatkârı tespit etmeye yardımcı olduğu gibi 1526 kayıtları içerisinde yer alan bilgiler de teşkilata dâhil edilmeden sarayda çalıştırılan başka sanatçıların varlığını ortaya koymaktadır. 1514 Çaldıran Zaferi sonrası aileleriyle birlikte Tebriz'den sürülen sanatkâr sayısı hakkında ise net bir bilgi bulunmamaktadır. İstanbul'a ulaştıkları halde Ehl-i hiref bünyesine hiçbir zaman alınmayan ve 1526 yll öncesi vefat ettikleri için de mevcut kayıtlarda görünmeyen sanatkârlar bulunmaktadır. Eğer Tebriz'den göçürülenlere dair Lütfi Paşa'nın verdiği 200 hane bilgisi dikkate alınırsa ki bu sayı İdrîs-i Bidlîsî ve Hoca Sadettin'in verdiği kişi saylları ile uyumludur, o zaman İstanbul'a gelenlerin en az yarısının sanatçı ailelerden oluştuğu eldeki veriler doğrultusunda rahatlıkla ileri sürülebilir. Tebrizli sanatkârların Osmanlı Sarayında yaklaşık bir asır süren etkinlikleri, devletlerarası siyasî ve kültürel ilişkilerin bir sonucu olduğu kadar, sanatı ve sanatçıyı himaye politikalarının, üretilen eserlere verilen destek ve teşviklerin ne kadar etkili ve de kıymetli olduğunu gösteren tarihimizdeki en güzel örneklerden biridir. 


\section{KAYNAKLAR}

\section{Arşiv Belgeleri}

Cumhurbaşkanlığı Osmanlı Arşivi (BOA)

Topkapı Sarayı Müzesi Arşivi (TSMA)

nr. D. 808, 4104, 6500, 9587, 9608, 9612, 9613/1, 9706/1, 9706/4, 9706/5, 9784, 10734

nr. E. 745/64 (E. 5475)

Kâmil Kepeci Tasnifi (KK.d.), nr. 1764

Maliyeden Müdevver Defterler Tasnifi (MAD.d.), nr. 23, 6196

Bâb-1 Defterî Müteferrik Defterler Tasnifi (D.M.d.), nr. 36806

\section{Kaynak Eserler ve Araştırmalar}

Arslan, Hüseyin, Osmanl'da Nïfus Hareketleri (XVI. Müzyll) Yönetim, Nïfus, Göçler, İskânlar, Sürgünler, İstanbul 2001.

Atik, Kayhan, Lütfi Paşa ve Tevâarih-i Âl-i Osman, Ankara 2001.

Barkan, Ömer Lûtfi, "H.933-934 (M.1527-1528) Malî yllına ait bir bütçe örneği”, İstanbul Üniversitesi Iktisat Fakïltesi Dergisi, G 15/S. 1-4 (Ekim 1953-Temmuz 1954), s. 251-329.

Bedirhan, Yaşar, “XII. ve XIII. Yüzyllda Kafkasya'dan Anadolu'ya Göç Eden İlim ve Fikir Adamları", Turkish Studies, C 9/S. 7 (2014), s. 193-213.

Bedirhan, Yaşar, "XI. XIV. Yüzylllarda Kafkasya Şehirlerinde İktisadi ve Sosyal Hayat (Tebriz Örneği), Akademik Sosyal Araştrrmalar Dergisi, S. 40 (Şubat 2017), s.181-210.

Bedirhan, Yaşar, "Ortaçağda Kafkasya Türk Şehirlerinde Esnaf Teşkilatları (Tebriz Örneği)", Bingöl Üniversitesi Sosyal Bilimler Enstitüsü Dergisi, C 7/S. 13 (2017), s. 223-236.

Beyazıt, Mustafa, "Erken Osmanl Devri'nde Tebrizli Usta Gruplarının İzi Nasıl Sürülmeli?", History Studies, C 6/ S. 3 (Nisan 2104), s. 45-70.

Bilgili, Ali Sinan, "Tebriz", Türkiye Diyanet Vakfi İslam Ansiklopedisi (TDVIA), G 40, İstanbul 2011, s. 219-222. 
Bilgin, Arif, "Harc-1 Hâssa Emini”, TDVIA, C Ek-1, İstanbul 2016, s. 535-536.

Bostan, İdris, "Kemal Reis", TDVİA, C 25, Ankara 2002, s. 226-227.

Celâl-zâde Mustafa, Selim-nâme, haz. Ahmet Uğur-Mustafa Çuhadar, Ankara 1990.

Çağman, Filiz, "Mimar Sinan Döneminde Saray'ın Ehl-i Hiref Teşkilatı", Mimar Sinan Dönemi Türk Mimarlğgr ve Sanatı, İstanbul 1988, s. 73-77.

Ekici, Sakine Akcan, 17. Yüzynlda Osmanl Devleti’nde Ehl-i Hiref-i Hâssa Teşkilatn Birimleri ve Yapısal Özellikleri, İstanbul Ün. Sosyal Bilimler Ens. Yayımlanmamış Doktora Tezi, İstanbul 2018.

Emecen, Feridun, Yavuz Sultan Selim, İstanbul 2016.

Eyice, Semavi, "Beyazıt II. Camii ve Külliyesi”, TDVİA, C 6, İstanbul 1992, s. 45-49.

Gök, İlhan, Atatürk Kitapluğ M.C. 0.71 Numaralı 909-933/1503-1527 Tarihli İnầmât Defteri (Transkripsiyon-Değerlendirme), Marmara Üniversitesi Türkiyat Araştırmaları Enstitüsü Yayımlanmamış Doktora Tezi, İstanbul 2014.

Haydar Çelebi Rûznâmesi (Feridun Bey, Münşeâtü's-Selâtîn, C I içinde, İstanbul 1274).

Heiderzadeh, Tofigh, "İran Alimlerinin Osmanlı Devletine Gelişi ve Osmanlı Bilimine Katkıları (Timur Döneminin Başından Safevi Döneminin Sonuna Kadar)", İngilizce'den çeviren: Aysu Albayrak, Osmanl Bilimi Araştrmalarl, S. 2 (1998), s. 211-242.

Hoca Mehmed Sadettin Efendi, Tâcü't-Tevârîh, G 2, İstanbul 1280.

Işınsu Durmuş, Tuba, "Siyasi Rekabetin Bir Enstrümanı Olarak Ortaçağ’da Sanat", Divan Edebiyat Araștrmalar Dergisi, S. 12 (2014), s. 65-76.

İdrîs-i Bidlîsî, Selîm Şâh-Nâme, haz. Hicabi Kırlangiç, Ankara 2016.

Kazan, Hilal, XVI. Asırda Sarayın Sanatı Himayesi, İstanbul 2010.

Kemal Paşazâde, Tevârih-i Âl-i Osman, IX. Defter, haz. Ahmet Uğur, The reign of Sultan Selim I in the light of the Selim-nâme literature, Berlin 1985.

Kırımtayıf, Süleyman, XV ve XIX. Yüzyllar Arasında Osmanlı Saray Sanatı Teşkilatı, İstanbul Teknik Ün. Sosyal Bilimler Ens. Yayımlanmamış Doktora Tezi, İstanbul 1996. 
Kökoğlu, Ali, Kemal Paşa-zâde’nin Selim-nâmesi, Erciyes Üniversitesi Sosyal Bilimler Enstitüsü Yayımlanmamış Yüksek Lisans Tezi, Kayseri 1994.

Malekzadeh, Farrokh, "İstanbul Topkapı Sarayı Müzesinde Bulunan Şah İsmail-i Safevi'ye Ait Kupa", İstanbul Üniversitesi Tarih Enstitüsü Dergisi, S. 7-8 (1976-1977), s. 263-276.

Meriç, Rıfkı Melûl, Türk Nakış San'atı Tarihi Araştırmaları 1 Vesikalar, Ankara 1953.

Muhyî Çelebi, Selim-nâme, Konya Koyunoğlu Müzesi Kitaplığı, nr.13335.

Sahillioğlu, Halil, "Emîn”, TDVİA, C 11, İstanbul 1995, s. 111-112.

Savaş, Vural, “Heşt Behişt Sarayı'ndan Topkapı Sarayı'na: Şah İsmail’in, Çaldıran Savaşı'ndan Sonra Alıkonulan Hazine ve Eşyaları", Toplumsal Tarih, S. 208 (Nisan 2011), s. 24-36.

Savaş, Vural, "From Tabrız to Istanbul: Goods and Treasures of Shāh Ismāīl Looted After The Battle of Chāldırān”, Studia Iranica, S. 44/2 (2015), s. 227-276.

Sümer, Faruk, “Akkoyunlular”, TDVIA, G 2, İstanbul 1989, s. 270-274.

Tanınd, Zeren, Türk Minyatür Sanatı, İstanbul 1996.

Tekindağ, Şehabettin, "Yeni Kaynak ve Vesikaların Işı̆̆ı Altında Yavuz Sultan Selim'in Iran Seferi", İstanbul Üniversitesi Edebiyat Fakültesi Tarih Dergisi, G 17 / S. 22 (Mart 1967), İstanbul 1968, s. 49-78.

Uluskan, Murat, “İstanbul'un Yapı Sanatkârları: Nakkaşlar ve Sıvacılar (17001838), Türk Kültürü İncelemeleri Dergisi, S. 28 (İstanbul 2013), s. 11-50.

Uzunçarşılı, İsmail Hakkı, “Osmanlı Sarayı'nda Ehl-i Hiref (Sanatkârlar) Defterleri”, Belgeler, C 11/ S. 15 (1986), s. 23-76.

Uzunçarşılı, İsmail Hakkı, Osmanlı Devletinin Saray Teşkilatı, Ankara 1988.

Uzunçarşılı, İsmail Hakkı, Anadolu Beylikleri, Akkoyunlu ve Karakoyunlu Devletleri, Ankara 1988.

Yaman, Bahattin, "1557 Tarihli Ehl-i Hıref Defterine Göre Osmanlı Saray Sanatkârları”, KÖK Araştırmalar, C 8/ S. 2 (Güz 2006), s. 5-38.

Yaman, Bahattin, "1545 Yılı Osmanlı Saray Sanatkârları”, Belleten, S. 264 (Ağustos 2008), s. 501-534.

Yaman, Bahattin, Osmanh Saray Sanatkârlar 18. Yüzylla Ehl-i Hiref, İstanbul 2008. 
EKLER

Ehl-i Hiref Maaş Defterlerinde Kayıtlı Tebrizli Sanatkârlar

(1526-1566)

Nakkaşlar

\begin{tabular}{|c|c|c|c|c|c|}
\hline \multicolumn{6}{|c|}{ Cemâaat-i Nakkāasân } \\
\hline \multirow{2}{*}{ İsim } & \multicolumn{4}{|c|}{ Yevmiye $[A k c ̧ e]$} & \multirow{2}{*}{ Açıklama } \\
\hline & 1526 & 1545 & 1557-58 & 1566 & \\
\hline $\begin{array}{l}\text { Şah Kulu } \\
\text { Ressâm }\end{array}$ & 22 & 25 & - & - & $\begin{array}{l}\text { Tebriz'den sürgün gelüp Amâsiyye'de cihet buyurulup } \\
\text { İstanbul Hâssa Harc'na havâle olunmuş ve ba dehu } \\
\text { mezkûr deftere ilhâk olunmuş. Fì gurre-i Muharrem } \\
\text { sene } 927 \text { (12 Aralık 1520). Ber-mûceb-i Rûz- } \\
\text { nâme. } \\
\text { (1514 yllında Şah İsmail'in sarayında bulunan } \\
\text { sanatkârlar arasındadır (TSMA, D.10734). } \\
1545 \text { tarihli maas defterinde Rûmiyân bölüğü } \\
\text { içinde olup isminin sonunda "Bağdâdî" ve } \\
\text { "Ser-bölük" kaydı bulunmaktadır. } 1564 \text { yok- } \\
\text { lamasında müteveffa listesinde olup } 1556 \text { 'da } \\
\text { vefat etmiştir. TSMA. D.4104) }\end{array}$ \\
\hline $\begin{array}{l}\text { Hasan bin } \\
\text { Muhammed }\end{array}$ & 20 & 22 & - & - & $\begin{array}{l}\text { Babası Hâssa Acem üstâdlanndan olup mezkûr kā- } \\
\text { biliyyet-birle Sultan Bâyezid Hân tâbe serâhâ evẩil- } \\
\text { lerinde cihet olunmus. } \\
\text { (1545 tarihli maaş defterinde Rûmiyân bölüğüu } \\
\text { içindedir. } 1564 \text { yoklamasında müteveffa lis- } \\
\text { tesinde olup 1545-1557 yllları arasında vefat } \\
\text { etmiştir.) }\end{array}$ \\
\hline $\begin{array}{c}\text { Melek Ahmed } \\
\text { Tebrîz } \hat{\imath}\end{array}$ & 24 & - & - & - & $\begin{array}{l}\text { Sultan Bâyezid Hân zamânnnda Acem'den gelïp cihet } \\
\text { olunmuş. } \\
\text { (Haziran } 1527 \text { 'de hayattadır (BOA, KK.d. } \\
\text { 1764, s.8). 1527-1545 ylları arasında vefat } \\
\text { etmiş olabilir.) }\end{array}$ \\
\hline $\begin{array}{l}\text { Hasan bin } \\
\text { Abdülcelil } \\
\text { Ressâm }\end{array}$ & 20,5 & - & - & - & $\begin{array}{l}\text { Babası Hâssa Acem üstâdlanndan olup mezkûr kā- } \\
\text { biliyyet-birle Sultan Bâyezid Hân tâbe serâhû zamâ- } \\
\text { ninda cihet olunmuș. } \\
\text { (1526-1545 ylları arasında vefat etmiş olabi- } \\
\text { lir.) }\end{array}$ \\
\hline $\begin{array}{l}\text { Hüseyin } \\
\text { Rûmı̂ }\end{array}$ & 12,5 & - & - & - & 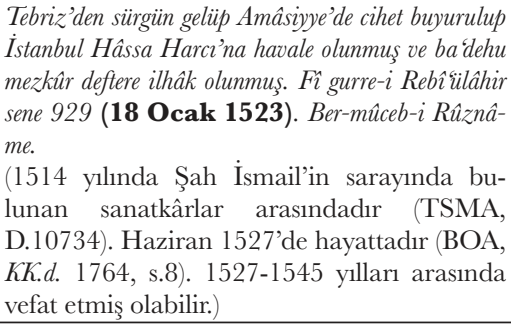 \\
\hline
\end{tabular}

Belleten, Aralık 2021, Cilt: 85/Sayı: 304; 849-887 


\begin{tabular}{|c|c|c|c|c|c|}
\hline $\begin{array}{l}\text { Ahmed } \\
\text { Rûmî }\end{array}$ & 10 & - & - & - & $\begin{array}{l}\text { Mislihu } \text { (Onun gibi) } \\
\text { (1526-1545 ylları arasında vefat etmiş olabi- } \\
\text { lir.) }\end{array}$ \\
\hline $\begin{array}{l}\text { Kāsım } \\
\text { İsfahânî }\end{array}$ & 12,5 & - & - & - & $\begin{array}{l}\text { Tebriz'den sürgün gelïp Amâsiyye'de cihet buyurulup } \\
\text { İstanbul Hâssa Harcina havale olunmuş ve ba 'dehu } \\
\text { mezkûr deftere ilhâk olunmuş. Fì gurre-i Rebîuilâahir } \\
\text { sene } 929 \text { (18 Ocak 1523). Ber-mûceb-i Rûznâ- } \\
\text { me. } \\
\text { (1564 yoklamasinda müteveffa listesinde olup } \\
1532-1545 \text { yllları arasinda vefat etmiştir.) }\end{array}$ \\
\hline $\begin{array}{c}\text { Hacı Beğ } \\
\text { Tebriž̂ }\end{array}$ & 10,5 & - & - & - & \begin{tabular}{|l} 
Mislihu \\
(1514 yllında Şah İsmail'in sarayında bulunan \\
sanatkârlar arasındadır (TSMA, D.10734). \\
1564 yoklamasında müteveffa listesinde olup \\
1532-1545 yılları arasında vefat etmiştir.)
\end{tabular} \\
\hline $\begin{array}{c}\text { Hoca Beğ } \\
\text { Tebrizî }\end{array}$ & 10,5 & - & - & - & $\begin{array}{l}\text { Mislihu } \\
\text { (1514 yllında Şah İsmail'in sarayında bu- } \\
\text { lunan sanatkârlar arasındadır (TSMA, } \\
\text { D.10734). Ocak 1532'de hayattadır (BOA, } \\
\text { KK.d. } 1764 \text {, s.158). 1532-1545 ylları arasında } \\
\text { vefat etmiş olabilir.) }\end{array}$ \\
\hline $\begin{array}{l}\text { Sultan Ali } \\
\text { Basmace }\end{array}$ & 9,5 & 12,5 & - & - & $\begin{array}{l}\text { Mislihu } \\
\text { (1545 tarihli maaş defterinde Acemân bölüğü } \\
\text { içindedir. 1564 yoklamasinda müteveffa lis- } \\
\text { tesinde olup 1545-1557 yılları arasinda vefat } \\
\text { etmiştir.) }\end{array}$ \\
\hline $\begin{array}{l}\text { Muhammed bin } \\
\text { Melek Ahmed }\end{array}$ & 7,5 & 9 & 10 & - & $\begin{array}{l}\text { San'at-birle yazılmış. Sultan Bâyezid Hân zamâ- } \\
\text { nında. } \\
\text { (1545 tarihli maaş defterinde Rûmiyân bölüğü } \\
\text { içindedir. } 1564 \text { yoklamasinda müteveffa lis- } \\
\text { tesinde olup R-C } 965 \text { / } 21 \text { Ocak-18 Nisan } \\
1558 \text { tarihleri arasinda vefat etmiştir. TSMA, } \\
\text { D.6500, vr.2a) }\end{array}$ \\
\hline $\begin{array}{c}\text { Ali } \\
\text { Birâdereş }\end{array}$ & 8 & 9 & - & - & $\begin{array}{l}\text { Mislihu } \\
\text { (1545 tarihli maaş defterinde Rûmiyân bölüğü } \\
\text { içindedir. } 1564 \text { yoklamasında müteveffa lis- } \\
\text { tesinde olup } 1545-1557 \text { yilları arasında vefat } \\
\text { etmiştir.) }\end{array}$ \\
\hline $\begin{array}{c}\text { Muhammed bin } \\
\text { Abdurrahman }\end{array}$ & 4,5 & 5,5 & 6,5 & - & $\begin{array}{l}\text { Babası Hâssa Acem üstâdlarndan olup mezkûr } \\
\text { san'at-birle yazlmış. Sultan Selim Hân zamânnnda. } \\
\text { (1545 ve 1557-58 tarihli maaş defterlerinde } \\
\text { Rummiyân bölüğ̈u içindedir. } 1564 \text { yoklamasinda } \\
\text { müteveffa listesinde olup 1558-1564 ylları } \\
\text { arasında vefat etmiştir.) }\end{array}$ \\
\hline
\end{tabular}




\begin{tabular}{|c|c|c|c|c|c|}
\hline $\begin{array}{l}\text { Şah Hüseyin } \\
\text { bin } \\
\text { Ressâm Hüsâm }\end{array}$ & 6 & - & - & - & $\begin{array}{l}\text { Babası Acem üstâdlarndan olup fevt oldukda mezkûr } \\
\text { san'at-birle yazılmış. F̂̀ } 14 \text { Cemâziyelâhir sene } 930 \\
(\mathbf{1 9} \text { Nisan 1524). Ber-mûceb-i Rûznâme. } \\
(1526 \text { yllıa ait bir diğer maaş defterinde } \\
\text { "Hüseyin" isminin başında "SSah" kaydı var- } \\
\text { dır (TSMA, D.9706/5). 1564 yoklamasında } \\
\text { müteveffa listesinde olup 1532-1545 yllar } \\
\text { arasinda vefat etmiştir.) }\end{array}$ \\
\hline $\begin{array}{c}\text { Abdülâlî } \\
\text { Tebrîzî }\end{array}$ & - & 20 & 20 & - & $\begin{array}{l}\text { Acemân bölüğü içindedir. } 1564 \text { yoklamasında } \\
\text { müteveffa listesinde olup 1558-1564 ylları } \\
\text { arasinda vefat etmiştir. }\end{array}$ \\
\hline $\begin{array}{l}\text { Abdülhamid } \\
\text { Tebrizzi }\end{array}$ & - & 15,5 & 16 & - & $\begin{array}{l}\text { Acemân bölüğü içindedir. } 1564 \text { yoklamasında } \\
\text { müteveffa listesinde olup 1558-1564 yllar1 } \\
\text { arasinda vefat etmiştir. }\end{array}$ \\
\hline $\begin{array}{l}\text { Şah } \\
\text { Muhammed } \\
\text { Tebrizî }\end{array}$ & - & 19 & 19,5 & 20,5 & $\begin{array}{l}\text { Tebriz'den getirilen sanatkârlar arasındadır } \\
\text { (TSMA, D.9784). 1526-1545 ylları arasında } \\
\text { Ehl-i Hiref defterine kaydedilmiştir. Acemân } \\
\text { bölüğ̈u içindedir. }\end{array}$ \\
\hline $\begin{array}{c}\text { Aliyüddin } \\
\text { Tebrizzî }\end{array}$ & - & 15 & - & - & $\begin{array}{l}\text { Acemân bölüğü içindedir. } 1564 \text { yoklamasında } \\
\text { müteveffa listesinde olup } 1545-1557 \text { yllar1 } \\
\text { arasinda vefat etmiştir. }\end{array}$ \\
\hline $\begin{array}{r}\text { Ali Beğ } \\
\text { Tebrizzî }\end{array}$ & - & 11 & - & - & $\begin{array}{l}\text { Tebriz'den getirilen sanatkârlar arasındadır } \\
\text { (TSMA, D.9784). 1526-1545 ylları arasında } \\
\text { Ehl-i hiref defterine kaydedilmiştir. Acemân } \\
\text { bölüğ̈̈ içindedir. } 1564 \text { yoklamasinda mü- } \\
\text { teveffa listesinde olup 1545-1557 arası vefat } \\
\text { etmiştir. }\end{array}$ \\
\hline $\begin{array}{l}\text { Abdülfettah } \\
\text { Tebrîzi }\end{array}$ & - & 12 & - & - & $\begin{array}{l}1515 \text { yılında Tebriz'den getirilen sanatkâr- } \\
\text { lar arasındadır (TSMA, D.9784). 1526-1545 } \\
\text { ylları arasında Ehl-i hiref defterine kay- } \\
\text { dedilmiştir. Acemân bölügü içindedir. 1564 } \\
\text { yoklamasında müteveffa listesinde olup 1545- } \\
1557 \text { arası vefat etmiştir. }\end{array}$ \\
\hline $\begin{array}{l}\text { Abdülhâlık } \\
\text { Tebrizzî }\end{array}$ & - & 12 & - & - & $\begin{array}{l}1515 \text { yllında Tebriz'den getirilen sanatkâr- } \\
\text { lar arasindadır (TSMA, D.9784). 1526-1545 } \\
\text { ylları arasında Ehl-i hiref defterine kay- } \\
\text { dedilmiştir. Acemân bölügü içindedir. } 1564 \\
\text { yoklamasında müteveffa listesinde olup 1545- } \\
1557 \text { arası vefat etmiştir. }\end{array}$ \\
\hline $\begin{array}{c}\text { Ahî Beğ } \\
\text { Tebrizzî }\end{array}$ & - & 10 & 10 & 10 & $\begin{array}{l}1515 \text { yllında Tebriz'den getirilen sanatkâr- } \\
\text { lar arasındadır (TSMA, D.9784). 1526-1545 } \\
\text { yllları arasında Ehl-i hiref defterine kaydedil- } \\
\text { miştir. Acemân bölüğü içindedir. }\end{array}$ \\
\hline $\begin{array}{c}\text { Ali Kulu } \\
\text { Tebrizzî }\end{array}$ & - & 3,5 & 4 & 6,5 & $\begin{array}{l}1515 \text { yllında Tebriz'den getirilen sanatkâr- } \\
\text { lar arasindadır (TSMA, D.9784). 1526-1545 } \\
\text { ylları arasında Ehl-i hiref defterine kaydedil- } \\
\text { miştir. Acemân bölüğü içindedir. }\end{array}$ \\
\hline
\end{tabular}




\begin{tabular}{|c|c|c|c|c|l|}
\hline $\begin{array}{c}\text { Mîr Aga/Emir } \\
\text { Ağa } \\
\text { Tebrizî }\end{array}$ & - & 5 & 7 & 12,5 & $\begin{array}{l}1515 \text { yllinda Tebriz'den getirilen sanatkâr- } \\
\text { lar arasındadır (TSMA, D.9784). 1526-1545 } \\
\text { ylları arasında Ehl-i hiref defterine kaydedil- } \\
\text { miştir. Acemân bölüğü içindedir. }\end{array}$ \\
\hline $\begin{array}{c}\text { Derviş } \\
\text { Muhammed } \\
\text { Isfahan }\end{array}$ & - & 1 & 3 & 10,5 & $\begin{array}{l}1545 \text { ve 1557-58 tarihli maaş defterlerinde } \\
\text { Acemân bölüğ̈ şâkirdlerindendir. }\end{array}$ \\
\hline Toplam Kişi & $\mathbf{1 4}$ & $\mathbf{1 7}$ & $\mathbf{9}$ & $\mathbf{5}$ & \multicolumn{1}{|c}{}
\end{tabular}

\section{Kuyumcular}

\begin{tabular}{|c|c|c|c|c|c|}
\hline \multicolumn{6}{|c|}{ Cemâ'at-i Zergerân } \\
\hline \multirow{2}{*}{ İsim } & \multicolumn{4}{|c|}{ Yevmiye $[A k c ̧ e]$} & \multirow{2}{*}{ Açıklama } \\
\hline & 1526 & 1545 & $1557-58$ & 1566 & \\
\hline $\begin{array}{c}\text { Hoca Mircan } \\
\text { Tebrizî }\end{array}$ & 26 & - & - & - & $\begin{array}{l}\text { Tebriz'den sürgün gelüp Amâsiyye'de cihet olunmuş. } \\
\text { (Ocak 1532'de hayattadır (BOA, KK.d. 1764, } \\
\text { s.158). } 1564 \text { yoklamasında müteveffa liste- } \\
\text { sinde olup 1532-1545 y1lları arasında vefat } \\
\text { etmiştir.) }\end{array}$ \\
\hline $\begin{array}{c}\text { Maksud Ali } \\
\text { Tebrî̋ }\end{array}$ & 20 & 28 & - & - & $\begin{array}{l}\text { Mislihu (Onun gibi) } \\
\text { (1514 yılında Şah İsmail'in sarayında bulu- } \\
\text { nan sanatkârlar arasında olup babasının adı } \\
\text { Hüdâbahş'dır (TSMA, D.10734). } 1545 \text { tarih- } \\
\text { li maaş defterinde Acemân bölügü içindedir. } \\
1564 \text { yoklamasında müteveffa listesinde olup } \\
\text { 1545-1557 yılları arasında vefat etmiştir.) }\end{array}$ \\
\hline $\begin{array}{l}\text { Hüseyin } \\
\text { Horasânî }\end{array}$ & 17 & - & - & - & $\begin{array}{l}\text { Mislihu } \\
\text { (1514 yılında Şah İsmail'in sarayında bu- } \\
\text { lunan sanatkârlar arasındadır (TSMA, } \\
\text { D.10734). Ocak 1532'de hayattadır (BOA, } \\
\text { KK.d. 1764, s.158). } 1564 \text { yoklamasında müte- } \\
\text { veffa listesinde olup } 1532-1545 \text { yılları arasın- } \\
\text { da vefat etmiştir.) }\end{array}$ \\
\hline $\begin{array}{c}\text { Derviş } \\
\text { Muhammed } \\
\text { Tebrîzi }\end{array}$ & 12,5 & 15 & - & - & $\begin{array}{l}\text { Mislihu } \\
\text { (1515 yılında Tebriz'den getirilen sanatkârlar } \\
\text { arasındadır (TSMA, D.9784). } 1545 \text { tarihli } \\
\text { maaş defterinde Acemân bölüğü içindedir. } \\
1564 \text { yoklamasında müteveffa listesinde olup } \\
\text { 1545-1557 ylları arasında vefat etmiştir.) }\end{array}$ \\
\hline $\begin{array}{c}\text { Hoşgelen/ } \\
\text { Hocagelen } \\
\text { Tebrî̌ }\end{array}$ & 10 & - & - & - & $\begin{array}{l}\text { Mislihu } \\
\text { (1515 yılında Tebriz'den getirilen sanatkâr- } \\
\text { lar arasındadır (TSMA, D.9784). Haziran } \\
\text { 1527'de hayattadır (BOA, KK.d. 1764, s.8). } \\
\text { 1564 yoklamasında müteveffa listesinde olup } \\
\text { 1532-1545 yılları arasında vefat etmiştir.) }\end{array}$ \\
\hline
\end{tabular}




\begin{tabular}{|c|c|c|c|c|c|}
\hline $\begin{array}{l}\text { Muzaffer bin } \\
\text { Mircan }\end{array}$ & 8,5 & 17 & 18,5 & 19,5 & $\begin{array}{l}\text { Babası Hâssa Acem üstâdlarndan olup san'at-birle } \\
\text { cihet olunmus. Fî̀ gurre-i Cemấziyelâhir sene } 928 \\
\mathbf{( 2 8} \text { Nisan 1522). Ber-mûceb-i Rûznâme } \\
\text { (1545 ve sonrası maaş defterlerinde Acemân } \\
\text { bölügüü içindedir.) }\end{array}$ \\
\hline $\begin{array}{l}\text { Hâşim } \\
\text { Tebrîzî }\end{array}$ & 7 & - & - & - & $\begin{array}{l}\text { Tebriz'den sürgün gelïp Amâsiyye'de cihet olunmuş. } \\
\text { (1526-1545 y1lları arasinda vefat etmiş ola- } \\
\text { bilir.) }\end{array}$ \\
\hline $\begin{array}{l}\text { Yâdigâr } \\
\text { Tebrizzî }\end{array}$ & 4 & - & - & - & $\begin{array}{l}\text { Tebriz'den sürgün gelïp san'at-birle yazılmıs. Fî } \\
25 \text { Rebîuilevvel sene } 928 \text { (22 Şubat 1522). } \\
\text { Ber-mûceb-i Rûznâme } \\
\text { (Ocak } 1532 \text { 'de hayattadır (BOA, KK.d. } 1764 \text {, } \\
\text { s.158). } 1532-1545 \text { ylları arasında vefat etmi̧̧ } \\
\text { olabilir.) }\end{array}$ \\
\hline $\begin{array}{l}\text { Derviş bin } \\
\text { Maksud Ali }\end{array}$ & 5 & - & - & - & $\begin{array}{l}\text { Babası Hâssa üstâdlardan olup mezkûra kābiliy- } \\
\text { yet-birle şâkird ulûfesi olunmuş. Fì } 25 \text { Rebîuilevvel } \\
\text { sene } 928 \text { (22 Şubat 1522). Ber-mûcebi-i Rûz- } \\
\text { nâme. } \\
\text { (1514 yllında Şah İsmail'in sarayında bu- } \\
\text { lunan sanatkârlar arasındadır (TSMA, } \\
\text { D.10734). } 1564 \text { yoklamasnda müteveffa lis- } \\
\text { tesinde olup } 1532-1545 \text { yllları arasinda vefat } \\
\text { etmiş̧tir.) }\end{array}$ \\
\hline $\begin{array}{l}\text { Hüseyin Çerkes } \\
\text { şâkird-i Mircan }\end{array}$ & 4,5 & - & - & - & $\begin{array}{l}\text { Şah İsmail kullarnndan Tebriz'de bulunup beğlik } \\
\text { olmus. } \\
\text { (1564 yoklamasında müteveffa listesinde olup } \\
1532-1545 \text { ylları arasinda vefat etmiştir.) }\end{array}$ \\
\hline $\begin{array}{l}\text { Sultan Kulu } \\
\text { şâkird-i Mircan }\end{array}$ & 2 & 9,5 & - & - & $\begin{array}{l}\text { Mislihu } \\
\text { (1515 yllında Tebriz'den getirilen sanatkârlar } \\
\text { arasındadır (TSMA, D.9784). } 1545 \text { tarihli } \\
\text { maaş defterinde Acemân bölüğ̈u içindedir. } \\
1564 \text { yoklamasinda müteveffa listesinde olup } \\
1545 \text { - } 1557 \text { yllları arasında vefat etmiştir.) }\end{array}$ \\
\hline $\begin{array}{l}\text { Mustafa bin } \\
\text { Pervâne } \\
\text { sakkird-i } \\
\text { Maksud Ali }\end{array}$ & 3 & - & - & - & $\begin{array}{l}\text { Babası Hâssa Acem üstâdlarndan olup fevt oldukda } \\
\text { mezkûra şâkird ulûfesi olunmus. Fì } 5 \text { Safer sene } 927 \\
\text { (15 Ocak 1521). Ber-mûceb-i Rüznâme. } \\
\text { (Babası } 1514 \text { yllında Tebriz'den göçürülenler } \\
\text { arasındadır. Kendisi 1526-1545 yılları ara- } \\
\text { sinda vefat etmiş olabilir.) }\end{array}$ \\
\hline $\begin{array}{l}\text { Şah Hüseyin bin } \\
\text { Şah Hasan }\end{array}$ & - & 26 & 27,5 & 29,5 & $\begin{array}{l}\text { Acemân bölüğüne mensuptur. } 1557-58 \\
\text { tarihli maaş defterinde, isminin sonunda } \\
\text { "Dökümcübaşı" kaydı vardır. }\end{array}$ \\
\hline $\begin{array}{l}\text { Sultan Kulu } \\
\quad \text { Çerkes }\end{array}$ & - & 5,5 & - & - & $\begin{array}{l}\text { Acemân bölüğüne mensuptur. } 1564 \\
\text { yoklamasinda müteveffa listesinde olup } \\
1545-1557 \text { yllları arasında vefat etmiştir. }\end{array}$ \\
\hline
\end{tabular}

Belleten, Aralık 2021, Cilt: 85/Sayı: 304; 849-887 


\begin{tabular}{|c|c|c|c|c|c|}
\hline $\begin{array}{l}\text { Burhan bin } \\
\text { Maksud Ali }\end{array}$ & - & 3 & - & - & Acemân bölüğüne mensuptur. \\
\hline $\begin{array}{c}\text { Ahmed bin } \\
\text { Mircan }\end{array}$ & - & 10 & - & - & Acemân bölüğüne mensuptur. \\
\hline $\begin{array}{c}\text { Muhammed bin } \\
\text { Mircan }\end{array}$ & - & 3 & - & - & Acemân bölüğüne mensuptur. \\
\hline $\begin{array}{l}\text { Mustafa bin } \\
\text { Mircan şâkird }\end{array}$ & - & - & - & - & $\begin{array}{l}1564 \text { yoklamasında müteveffa listesindedir. } \\
1526 \text { yılı sonrası Ehl-i hiref defterine kayde- } \\
\text { dilip } 1532-1545 \text { yılları arasında vefat etmiştir. }\end{array}$ \\
\hline Toplam Kişi & 12 & 9 & 2 & 2 & \\
\hline
\end{tabular}

Altın Kakmacilar

\begin{tabular}{|c|c|c|c|c|c|}
\hline \multicolumn{6}{|c|}{ Cemâat-i Zernişânî } \\
\hline \multirow{2}{*}{ İsim } & \multicolumn{4}{|c|}{ Yevmiye $[A k c ̧ e]$} & \multirow{2}{*}{ Açıklama } \\
\hline & 1526 & 1545 & $1557-58$ & 1566 & \\
\hline $\begin{array}{c}\text { İsmail bin } \\
\text { Abdullah } \\
\text { Tebrizzî }\end{array}$ & 28 & 28 & 28,5 & - & $\begin{array}{l}\text { Tebriz'den sürgün gelïp Amâsiyye'de cihet olunmuş. } \\
\text { (1514 ylında Şah İsmail'in sarayında bu- } \\
\text { lunan sanatkârlar arasındadır (TSMA, } \\
\text { D.10734). Babasının adı } 1545 \text { tarihli maş̧ } \\
\text { defterinde kayıtlıdır. } 1564 \text { yoklamasında } \\
\text { hayattadır. 1564-1566 ylları arasında vefat } \\
\text { etmiş olabilir.) }\end{array}$ \\
\hline $\begin{array}{l}\text { Hüseyin bin } \\
\text { Cemaleddin }\end{array}$ & 20 & 23 & 24 & 24 & $\begin{array}{l}\text { Mislihu }(\text { Onun gibi) } \\
\text { (Babası } 1514 \text { yllında Şah İsmail'in sarayın- } \\
\text { da bulunan sanatkârlar arasındadır (TSMA, } \\
\text { D.10734). }\end{array}$ \\
\hline $\begin{array}{l}\text { Mîrim bin } \\
\text { Cemâleddin }\end{array}$ & 6,5 & - & - & - & 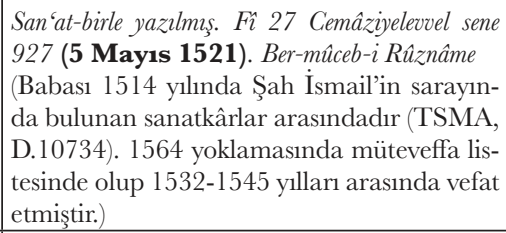 \\
\hline $\begin{array}{c}\text { Mesud } \\
\text { Şirâzî }\end{array}$ & 12 & 15,5 & 20,5 & 21,5 & 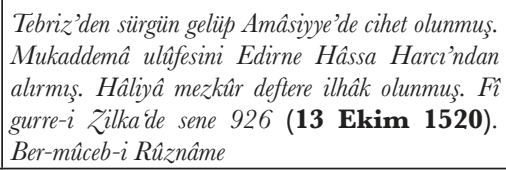 \\
\hline $\begin{array}{c}\text { Ali Beğ } \\
\text { Tebriżî }\end{array}$ & 10,5 & 14,5 & - & - & $\begin{array}{l}\text { San'at-birle yazılmuş. F̂̉ } 22 \text { Cemâzivelevvel sene } \\
928 \text { (19 Nisan 1522). Ber-mûceb-i Rûznâme } \\
\text { (1564 yoklamasinda müteveffa listesinde } \\
\text { olup } 1545-1557 \text { ylları arasinda vefat etmiş- } \\
\text { tir.) }\end{array}$ \\
\hline
\end{tabular}




\begin{tabular}{|c|c|c|c|c|c|}
\hline $\begin{array}{l}\text { Ayas } \\
\text { Çerkes }\end{array}$ & 6 & 13 & 16 & 16,5 & $\begin{array}{l}\text { Sah İsmail kullarndan Tebriz'de bulunup beğglik } \\
\text { olmuş. Fî } 28 \text { Rebîuilevvel sene } 926 \text { (18 Mart } \\
\text { 1520). Ber-mûceb-i Rûznâme }\end{array}$ \\
\hline $\begin{array}{l}\text { Muhammed bin } \\
\text { Kāsım } \\
\text { şâkird-i Cemaleddin }\end{array}$ & 6 & 14,5 & 24 & - & $\begin{array}{l}\text { Babası Hâssa Acem üstâdlarnndan olup fevt olduk- } \\
\text { da mezkâra şâkird ulâfesi olunmuş. Sultan Selim } \\
\text { Hân zamânnda. } \\
\text { (Babası } 1514 \text { yılında Şah İsmail'in sarayın- } \\
\text { da bulunan sanatkârlar arasındadır (TSMA, } \\
\text { D.10734). 1557-58 tarihli maaş defterinde, } \\
\text { isminin başında "Şah" unvanı vardır. } 1564 \\
\text { yoklamasında hayattadır. 1564-1566 ylları } \\
\text { arasında vefat etmiş olabilir.) }\end{array}$ \\
\hline $\begin{array}{l}\text { Ali bin Kāsım } \\
\text { şâkird-i Mesud }\end{array}$ & 2 & - & - & - & $\begin{array}{l}\text { Babası Hâssa Acem üstâdlarndan olup fevt olduk- } \\
\text { da mezkûra şâkird ulâfesi olunmuş. Sultan Selim } \\
\text { Hân zamânnda. } \\
\text { (Babası } 1514 \text { yılında Şah İsmail'in sarayın- } \\
\text { da bulunan sanatkârlar arasındadır (TSMA, } \\
\text { D.10734). Kendisi 1526-1545 yılları arasın- } \\
\text { da vefat etmiş olabilir.) }\end{array}$ \\
\hline $\begin{array}{l}\text { İmad Beğ bin } \\
\text { Şemseddin Ali }\end{array}$ & 2 & - & - & - & $\begin{array}{l}\text { Babası Acem Hâssa üstâdlarndan olup fevt oldukda } \\
\text { mezkûra şâkird ulûfesi olmuş. Fî } 5 \text { Muharrem sene } \\
932 \text { (22 Ekim 1525). Ber-mûceb-i Rüznâme } \\
\text { (Babası } 1514 \text { yılında Şah İsmail'in sarayın- } \\
\text { da bulunan sanatkârlar arasındadır (TSMA, } \\
\text { D.10734). Kendisi 1526-1545 yılları arasın- } \\
\text { da vefat etmiş olabilir.) }\end{array}$ \\
\hline Toplam Kişi & 9 & 6 & 5 & 3 & \\
\hline
\end{tabular}

\section{Altın veya Gümüşle Kakma ve Çakma Süsleme Yapanlar}

\begin{tabular}{|c|c|c|c|c|c|}
\hline \multicolumn{6}{|c|}{ Cemâat-i Kûftegerân } \\
\hline \multirow{2}{*}{ İsim } & \multicolumn{4}{|c|}{ Yevmiye $[A k c ̧ e]$} & \multirow{2}{*}{ Açıklama } \\
\hline & 1526 & 1545 & 1557-58 & 1566 & \\
\hline $\begin{array}{c}\text { Muhammed } \\
\text { Can } \\
\text { Tebrîzi }\end{array}$ & 16,5 & - & - & - & 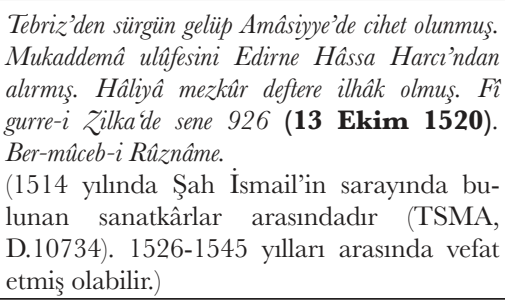 \\
\hline $\begin{array}{c}\text { Mîr Hüseyin } \\
\text { Tebrîzi }\end{array}$ & - & 8 & - & - & $\begin{array}{l}1515 \text { yllında Tebriz'den getirilen sanatkâr- } \\
\text { lar arasındadır (TSMA, D.9784). } 1526 \text { yllı } \\
\text { sonrası Ehl-i hiref defterine kaydedilmiştir. } \\
1564 \text { yoklamasında müteveffa listesinde olup } \\
1545-1557 \text { ylları arasında vefat etmiştir. }\end{array}$ \\
\hline Toplam Kişi & 1 & 1 & - & - & \\
\hline
\end{tabular}

Belleten, Aralık 2021, Cilt: 85/Sayı: 304; 849-887 


\section{Değerli Taş Yontucu ve Yerleştiriciler}

\begin{tabular}{|c|c|c|c|c|c|}
\hline \multicolumn{6}{|c|}{ Cemấat-i Hakkâkin } \\
\hline \multirow{2}{*}{ İsim } & \multicolumn{4}{|c|}{ Yevmiye $[A k c ̧ e]$} & \multirow{2}{*}{ Açıklama } \\
\hline & 1526 & 1545 & $1557-58$ & 1566 & \\
\hline $\begin{array}{l}\text { Şirem } \\
\text { Horasân̂ }\end{array}$ & 22 & - & - & & 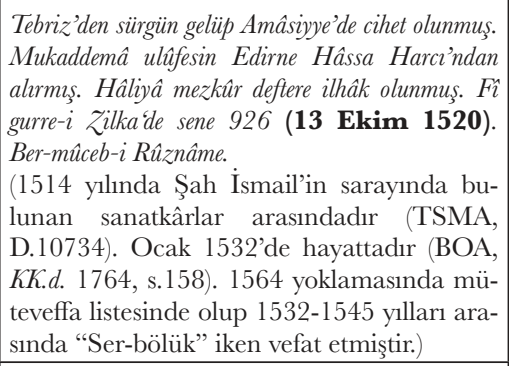 \\
\hline Şah Kulu & 5 & - & - & - & $\begin{array}{l}\text { San'at-birle yazılmuş. Fî } 24 \text { Rebîuilâhir sene } 930 \\
\text { (1 Mart 1524). Ber-mûceb-i Rüznâme } \\
\text { (1526-1545 yilları arasında vefat etmiş ola- } \\
\text { bilir.) }\end{array}$ \\
\hline $\begin{array}{c}\text { Sultan Ali } \\
\text { Tebriž̂ }\end{array}$ & - & - & - & - & $\begin{array}{l}1515 \text { yılında Tebriz'den getirilen sanatkâr- } \\
\text { lar arasındadır (TSMA, D.9784). } 1526 \text { yllı } \\
\text { sonrası Ehl-i hiref defterine kaydedilmiştir. } \\
1564 \text { yoklamasında müteveffa listesinde olup } \\
1532-1545 \text { yılları arasında vefat etmiştir. } \\
\end{array}$ \\
\hline Toplam Kişi & 2 & - & - & - & \\
\hline
\end{tabular}

\section{Altın ve Gümüşten Tel Çekip Sırma İşleyenler (Sırmakeşler)}

\begin{tabular}{|c|c|c|c|c|c|}
\hline \multicolumn{6}{|c|}{ Cemấat-i Sìmkeşân } \\
\hline \multirow{2}{*}{ İsim } & \multicolumn{4}{|c|}{ Yevmiye $[A k c ̧ e]$} & \multirow{2}{*}{ Açıklama } \\
\hline & 1526 & 1545 & $1557-58$ & 1566 & \\
\hline $\begin{array}{c}\text { Mîr Ahmed } \\
\text { Tebrîzi }\end{array}$ & 12 & - & - & - & $\begin{array}{l}\text { Tebriz'den sürgün gelïp Amâsiyye'de cihet olunmus. } \\
\text { Mukaddemâ ulûfesin İstanbul Hâssa Harcı'ndan } \\
\text { alrrmıs. Hâliyâa mezkûr deftere ilhâk olunmuş. Fì gur- } \\
\text { re-i Receb sene } 929 \text { (16 Mayıs 1523). Ber-mû- } \\
\text { ceb-i Rûzznâme } \\
\text { (1564 yoklamasinda "Sikkekenân" sinıfi için- } \\
\text { de müteveffa listesinde olup 1532-1545 yılları } \\
\text { arasinda vefat etmiştir.) }\end{array}$ \\
\hline $\begin{array}{c}\text { Abdülâlî } \\
\text { Tebrîzî }\end{array}$ & - & - & - & - & $\begin{array}{l}1564 \text { yoklamasında müteveffa listesindedir. } \\
1526 \text { y1lı sonrası Ehl-i hiref defterine kayde- } \\
\text { dilip 1532-1545 ylları arasinda vefat etmiştir. }\end{array}$ \\
\hline Toplam Kişi & 2 & - & - & - & \\
\hline
\end{tabular}




\section{Altın İplikle İşleme Yapanlar}

\begin{tabular}{|c|c|c|c|c|c|}
\hline \multicolumn{6}{|c|}{ Cemâ'at-i Zerdûzân } \\
\hline \multirow{2}{*}{ İsim } & \multicolumn{4}{|c|}{ Yevmiye $[A k c c e]$} & \multirow{2}{*}{ Açıklama } \\
\hline & 1526 & 1545 & 1557-58 & 1566 & \\
\hline Bülbül & 8 & - & - & - & $\begin{array}{l}\text { Tebriz'den sürgün gelüp Amâsiyye'de cihet olunmuş. } \\
\text { Mukaddemâ ulufesin Edirne Hâssa Harcı'ndan alır- } \\
\text { mıs. Hâliyâ mezkûr deftere ilhâk olunmuş. Fî } 25 \mathrm{Mu} \text { - } \\
\text { harrrem sene } 926 \text { (16 Ocak 1520). Ber-mûceb-i } \\
\text { Rûznâme } \\
\text { (1526-1545 yılları arasında vefat etmiş olabi- } \\
\text { lir.) }\end{array}$ \\
\hline $\begin{array}{c}\text { Beşâret } \\
\text { Gürcü }\end{array}$ & 4,5 & 9,5 & 11 & 12,5 & $\begin{array}{l}\text { Şah Ismail kullarndan Tebriz'de bulunup beğlik } \\
\text { olmus. Mukaddemâ ulûfesini İstanbul Hâssa } \\
\text { Harcı'ndan altrmıs. Hâliyâ mezkûr deftere ilhâk } \\
\text { olunmuş. Fî } 25 \text { Muharrem sene } 926 \text { (16 Ocak } \\
\text { 1520). Ber-mûceb-i Rûznâme }\end{array}$ \\
\hline Toplam Kişi & 2 & 1 & 1 & 1 & \\
\hline
\end{tabular}

\section{Kilıççılar}

\begin{tabular}{|c|c|c|c|c|c|}
\hline \multicolumn{6}{|c|}{ Cemấat-i Şimşîrgerân } \\
\hline \multirow{2}{*}{ İsim } & \multicolumn{4}{|c|}{ Yevmiye $[\mathrm{Akçe}]$} & \multirow{2}{*}{ Açıklama } \\
\hline & 1526 & 1545 & $1557-58$ & 1566 & \\
\hline $\begin{array}{c}\text { Halil bin } \\
\text { Şeyh Hasan } \\
\text { Tebriẑ̂ }\end{array}$ & 14 & 14,5 & - & - & $\begin{array}{l}\text { Tebriz'den sürgün gelüp Amâsiyye'de cihet olunmuş. } \\
\text { Mukaddemâ ulûfesin Edirne Hâssa Harci'ndan alup } \\
\text { ba 'dehu mezkûr deftere ilhâk olunmuş. Fî gurre-i } \\
\text { Safer sene } 927 \text { (11 Ocak 1521). Ber-mûceb-i } \\
\text { Râznâme. } \\
\text { (Aynı sanat dalında çalışan babasıyla birlikte } \\
\text { Tebriz'den göçürülenler arasındadır. } 1564 \\
\text { yoklamasında müteveffa listesinde olup 1545- } \\
1557 \text { yılları arasında vefat etmiştir.) }\end{array}$ \\
\hline $\begin{array}{c}\text { Mîr Şeyh } \\
\text { Tebrîzi }\end{array}$ & 12,5 & - & - & - & $\begin{array}{l}\text { San'at-birle yazılmış. Fî } 24 \text { Cemâziyelevvel sene } \\
926 \text { (12 Mayıs 1520). Ber-mûceb-i Rûznâme } \\
\text { (1526-1545 yılları arasında vefat etmiş ola- } \\
\text { bilir.) }\end{array}$ \\
\hline Toplam Kişi & 2 & 1 & - & - & \\
\hline
\end{tabular}

Belleten, Aralık 2021, Cilt: 85/Sayı: 304; 849-887 


\section{Kalkancilar}

\begin{tabular}{|c|c|c|c|c|c|}
\hline \multicolumn{6}{|c|}{ Cemâát-i Siperdûzân } \\
\hline \multirow{2}{*}{ İsim } & \multicolumn{4}{|c|}{ Yevmiye $[A k c ̧ e]$} & \multirow{2}{*}{ Açıklama } \\
\hline & 1526 & 1545 & 1557-58 & 1566 & \\
\hline $\begin{array}{l}\text { Abdüllatif } \\
\text { Mervî }\end{array}$ & 9 & - & - & - & 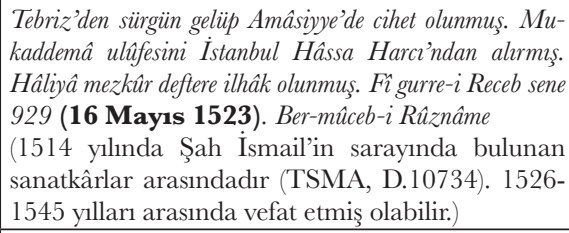 \\
\hline $\begin{array}{c}\text { Hacı } \\
\text { Muhammed } \\
\text { Mervî }\end{array}$ & 8 & 8 & - & - & $\begin{array}{l}\text { Mislihu } \text { (Onun gibi) } \\
\text { (1514 yllında Şah İsmail'in sarayında bulunan } \\
\text { sanatkârlar arasındadır (TSMA, D.10734). } 1564 \\
\text { yoklamasında müteveffa listesinde olup 1545-1557 } \\
\text { ylları arasında vefat etmiştir.) }\end{array}$ \\
\hline $\begin{array}{l}\text { Abdürrahim } \\
\text { Horasân̂̀ }\end{array}$ & 6 & 7,5 & - & - & $\begin{array}{l}\text { Mislihu } \\
\text { (1564 yoklamasında müteveffa listesinde olup } \\
\text { 1545-1557 ylları arasında vefat etmiştir.) }\end{array}$ \\
\hline $\begin{array}{l}\text { Şah Hüseyin } \\
\text { Horasân̂ิ }\end{array}$ & 5 & 5 & - & - & $\begin{array}{l}\text { Mislihu } \\
\text { (1564 yoklamasinda müteveffa listesinde olup } \\
\text { 1545-1557 y1lları arasinda vefat etmiştir.) }\end{array}$ \\
\hline $\begin{array}{l}\text { Derviş } \\
\text { Muhammed } \\
\text { Tebrîzî }\end{array}$ & - & 15 & - & - & $\begin{array}{l}1564 \text { yoklamasında müteveffa listesinde olup } \\
1545-1557 \text { yllları arasında vefat etmiştir. }\end{array}$ \\
\hline Toplam Kişi & 4 & 4 & - & - & \\
\hline
\end{tabular}

Bıçakçılar ile Eğeciler vd.

\begin{tabular}{|c|c|c|c|c|c|}
\hline \multicolumn{6}{|c|}{ Cemấat-i Kârdgerân ma'a Sühengerân ve gayruhu } \\
\hline \multirow{2}{*}{ İsim } & \multicolumn{4}{|c|}{ Yevmiye $[A k c ̧ e]$} & \multirow{2}{*}{ Açıklama } \\
\hline & 1526 & 1545 & 1557-58 & 1566 & \\
\hline $\begin{array}{l}\text { Çâlâk } \\
\text { Mikrâzî }\end{array}$ & 6 & - & - & - & 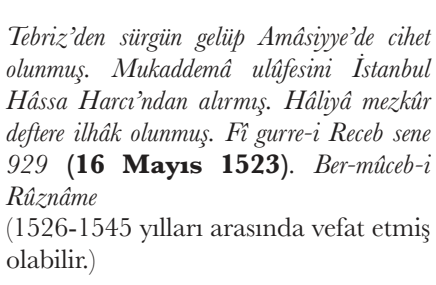 \\
\hline
\end{tabular}




\begin{tabular}{|c|c|c|c|c|c|}
\hline $\begin{array}{l}\text { Şîr Muhammed } \\
\text { Tebrîî }\end{array}$ & - & 8 & 10 & 11,5 & $\begin{array}{l}1564 \text { yoklamasında hayatta olup ismi- } \\
\text { nin üzerinde "Kolçağ̂̀" kaydı vardır. }\end{array}$ \\
\hline Toplam Kişi & $\mathbf{1}$ & 1 & 1 & $\mathbf{1}$ & \\
\hline
\end{tabular}

\section{Kazancılar, Bakırcılar}

\begin{tabular}{|c|c|c|c|c|c|}
\hline \multicolumn{6}{|c|}{ Cemấat-i Kazgāanyân } \\
\hline \multirow{2}{*}{ İsim } & \multicolumn{4}{|c|}{ Yevmiye $[A k c ̧ e]$} & \multirow{2}{*}{ Açıklama } \\
\hline & 1526 & 1545 & $1557-58$ & 1566 & \\
\hline $\begin{array}{c}\text { Necmeddin } \\
\text { Tebrîzi }\end{array}$ & 12 & - & - & - & $\begin{array}{l}\text { Tebriz'den sürgün gelüp Amâsiyye'de cihet } \\
\text { olunmuş. Mukaddemâ ulûfesini Hâssa Har- } \\
\text { cı'ndan alırmıs. Hâliyâ mezkûr deftere ilhâk } \\
\text { olmuş. Fì gurre-i Receb sene } 929 \text { (16 Mayıs } \\
\mathbf{1 5 2 3 ) . ~ B e r - m u ̂ c e b - i ~ R u ̂ z n a ̂ m e . ~} \\
\text { (1564 yoklamasinda müteveffa listesinde } \\
\text { olup 1532-1545 y1lları arasinda vefat } \\
\text { etmiştir.) }\end{array}$ \\
\hline $\begin{array}{c}\text { Hâcegî̀ } \\
\text { Tebrîzî Misger }\end{array}$ & - & 8,5 & - & - & $\begin{array}{l}1515 \text { yılında Tebriz'den getirilen sanat- } \\
\text { kârlar arasındadır (TSMA, D.9784). } \\
1564 \text { yoklamasında müteveffa listesinde } \\
\text { olup 1545-1557 yılları arasında vefat } \\
\text { etmiştir. }\end{array}$ \\
\hline Toplam Kişi & $\mathbf{1}$ & $\mathbf{1}$ & - & - & \\
\hline
\end{tabular}

\section{Çiniciler}

\begin{tabular}{|c|c|c|c|c|c|}
\hline \multicolumn{6}{|c|}{ 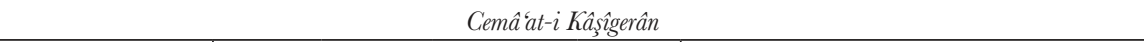 } \\
\hline \multirow{2}{*}{ İsim } & \multicolumn{4}{|c|}{ Yevmiye $[A k c ̧ e]$} & \multirow{2}{*}{ Açıklama } \\
\hline & 1526 & 1545 & $1557-58$ & 1566 & \\
\hline $\begin{array}{l}\text { Habib } \\
\text { Tebriż人 }\end{array}$ & 8,5 & - & - & - & $\begin{array}{l}\text { San'at-birle cihet olunup mukaddemâ ulâfesini } \\
\text { İstanbul Hâssa Harcindan alup hâliyâ mezkûr } \\
\text { deftere ilhâk olunmuş. Fì gurre-i Receb sene } 929 \\
\text { (16 Mayis 1523). Ber-mûceb-i Rûznâme } \\
\text { (1526-1545 yılları arasinda vefat etmiş } \\
\text { olabilir.) }\end{array}$ \\
\hline Toplam Kişi & 1 & - & - & - & \\
\hline
\end{tabular}


Kürkçüler

\begin{tabular}{|c|c|c|c|c|c|}
\hline \multicolumn{6}{|c|}{ Cemấat-i Postîndûzân } \\
\hline \multirow{2}{*}{ İsim } & \multicolumn{4}{|c|}{ Yevmiye $[A k c ̧ e]$} & \multirow{2}{*}{ Açıklama } \\
\hline & 1526 & 1545 & $1557-58$ & 1566 & \\
\hline $\begin{array}{c}\text { Ahmed bin } \\
\text { Hacı Lütfullah }\end{array}$ & 2 & - & - & - & $\begin{array}{l}\text { Babast Hâssa Acem üstâdlarndan olup fevt oldukda mezkûra } \\
\text { şâkird ulûfesi olunmuşs. Fî } 26 \text { Ramazân sene } 929 \text { (8 Ağus- } \\
\text { tos 1523). Ber-mûceb-i Rüznâme. } \\
\text { (1564 yoklamasnda müteveffa listesinde olup 1532- } \\
1545 \text { ylları arasinda vefat etmiştir.) }\end{array}$ \\
\hline Toplam Kişi & 1 & - & - & - & \\
\hline
\end{tabular}

Aba Dokuyucular

\begin{tabular}{|c|c|c|c|c|c|}
\hline \multicolumn{6}{|c|}{ Cemâat $-i$ Abâyî̉ââân } \\
\hline \multirow[t]{2}{*}{ İsim } & \multicolumn{4}{|c|}{ Yevmiye $[A k c ̧ e]$} & \multirow[t]{2}{*}{ Açıklama } \\
\hline & 1526 & 1545 & $1557-58$ & 1566 & \\
\hline $\begin{array}{c}\text { Muhammed } \\
\text { Can } \\
\text { Tebrîzî }\end{array}$ & 14 & - & - & - & $\begin{array}{l}\text { Tebriz'den sürgün olup Amâsiyye'de cihet olunmus. Mu- } \\
\text { kaddemâ ulûfesini İstanbul Hâssa Harcindan alup hâliyâa } \\
\text { mezkûr deftere ilhâk olunmus. Fồ gurre-i Muharrem sene } 927 \\
\text { (12 Aral1k 1520). Ber-mûceb-i Rûznâme. } \\
\text { (1564 yoklamasinda müteveffa listesinde olup 1532- } \\
1545 \text { ylları arasinda vefat etmiştir.) } \\
\end{array}$ \\
\hline $\begin{array}{l}\text { Mirek } \\
\text { Tebrizî }\end{array}$ & 7,5 & - & - & - & $\begin{array}{l}\text { San'at-birle yazılmış. Fì } 12 \text { Zilhicce sene } 926 \text { (23 Ka- } \\
\text { sim 1520) Ber-mûceb-i Rûznâme } \\
\text { (Tebrizli olduğu } 1564 \text { yoklamasında müteveffa lis- } \\
\text { tesinde belirtilmiş olup } 1532-1545 \text { ylları arasında } \\
\text { vefat etmiştir.) }\end{array}$ \\
\hline $\begin{array}{l}\text { Mîr Hasan } \\
\text { Tebrîzî }\end{array}$ & - & 7 & - & - & $\begin{array}{l}1564 \text { yoklamasında müteveffa listesinde olup 1545- } \\
1557 \text { ylları arasında vefat etmiştir. }\end{array}$ \\
\hline Toplam Kişi & 2 & 1 & - & - & \\
\hline
\end{tabular}

Takkeciler

\begin{tabular}{|c|c|c|c|c|c|}
\hline \multicolumn{6}{|c|}{ Cemấat-i Külâhdûzân } \\
\hline \multirow{2}{*}{ İsim } & \multicolumn{4}{|c|}{ Yevmiye $[A k c ̧]$} & \multirow{2}{*}{ Açılklama } \\
\hline & 1526 & 1545 & $1557-58$ & 1566 & \\
\hline $\begin{array}{c}\text { Pervâne } \\
\text { Tebrizî }\end{array}$ & - & - & - & - & $\begin{array}{l}1564 \text { yoklamasında müteveffa listesindedir. } 1526 \text { yll } \\
\text { sonrası Ehl-i hiref defterine kaydedilip } 1532-1545 \\
\text { ylları arasında vefat etmiştir. }\end{array}$ \\
\hline Toplam Kişi & (1) & - & - & - & \\
\hline
\end{tabular}


Ciltçiler

\begin{tabular}{|c|c|c|c|c|c|}
\hline \multicolumn{6}{|c|}{ Cemâat-i Mücellidân } \\
\hline \multirow{2}{*}{ İsim } & \multicolumn{4}{|c|}{ Yevmiye $[A k c ̧ e]$} & \multirow{2}{*}{ Açıklama } \\
\hline & 1526 & 1545 & $1557-58$ & 1566 & \\
\hline $\begin{array}{c}\text { Ali Beğ } \\
\text { Tebrizzî }\end{array}$ & - & - & - & - & $\begin{array}{l}1564 \text { yoklamasında müteveffa listesindedir. } 1526 \text { yll } \\
\text { sonrası Ehl-i hiref defterine kaydedilip } 1532-1545 \\
\text { yılları arasında vefat etmiştir. }\end{array}$ \\
\hline Toplam Kiși & (1) & - & - & - & \\
\hline
\end{tabular}

Hattatlar

\begin{tabular}{|c|c|c|c|c|c|}
\hline \multicolumn{6}{|c|}{ Cemấat-i Kâtibân-ı Kütüb } \\
\hline \multirow{2}{*}{ İsim } & \multicolumn{4}{|c|}{ Yevmiye $[\mathrm{A} k \mathrm{cs}]$} & \multirow{2}{*}{ Açıklama } \\
\hline & 1526 & 1545 & 1557-58 & 1566 & \\
\hline $\begin{array}{l}\text { Abdurrahim bin } \\
\text { Abdullah }\end{array}$ & 10,5 & 12 & - & - & 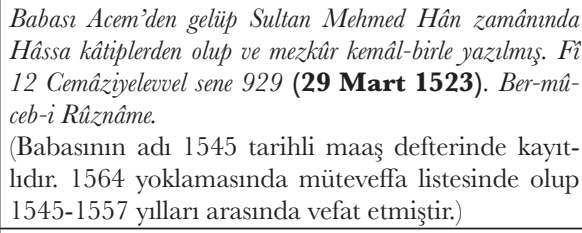 \\
\hline $\begin{array}{l}\text { Abdülvâhid } \\
\text { Tebrîzî }\end{array}$ & - & 11 & 11 & 12 & $\begin{array}{l}1515 \text { yllında Tebriz'den gelen sanatkârlar arasın- } \\
\text { dadır (TSMA, D.9784). 1526-1545 ylları arasında } \\
\text { Ehl-i hiref defterine kaydedilmiştir. } \\
\end{array}$ \\
\hline $\begin{array}{l}\text { Yusuf } \\
\text { Tebrizi }\end{array}$ & - & 15 & - & - & $\begin{array}{l}\text { 1526-1545 yılları arasında Ehl-i hiref defterine kay- } \\
\text { dedilmiştir. }\end{array}$ \\
\hline $\begin{array}{l}\text { Sultan Ali } \\
\text { Tebrizî }\end{array}$ & - & - & - & - & $\begin{array}{l}1514 \text { ylında Şah İsmail'in sarayında bulunup } \\
\text { (TSMA, D.10734) 1515 yllında getirilen sanatkârlar } \\
\text { arasindadır (TSMA, D.9784). } 1564 \text { yoklamasında } \\
\text { müteveffa listesindedir. 1526 yll sonrası Ehl-i hiref } \\
\text { defterine kaydedilip 1532-1545 ylları arasında ve- } \\
\text { fat etmiştir. }\end{array}$ \\
\hline Toplam Kişi & 1 & 3 & 1 & 1 & \\
\hline
\end{tabular}

\section{Cerrahlar}

\begin{tabular}{|c|c|c|c|c|c|}
\hline \multicolumn{6}{|c|}{ Cemấat-i Cerrâhîn } \\
\hline \multirow[t]{2}{*}{ İsim } & \multicolumn{4}{|c|}{ Yevmiye $[A k c ̧ e]$} & \multirow[t]{2}{*}{ Açıklama } \\
\hline & 1526 & 1545 & $1557-58$ & 1566 & \\
\hline $\begin{array}{c}\text { Hasan } \\
\text { Tebriżî Cerrâh }\end{array}$ & - & - & - & - & $\begin{array}{l}1564 \text { yoklamasinda müteveffa listesindedir. } 1526 \\
\text { yll sonrası Ehl-i hiref defterine kaydedilip } 1532 \text { - } \\
1545 \text { ylları arasında vefat etmiştir. }\end{array}$ \\
\hline Toplam Kişi & (1) & - & - & - & \\
\hline
\end{tabular}

Belleten, Aralık 2021, Cilt: 85/Sayı: 304; 849-887 
Güreşçiler

\begin{tabular}{|c|c|c|c|c|c|}
\hline \multicolumn{6}{|c|}{ Cemấat-i Küștigîrân } \\
\hline \multirow{2}{*}{ İsim } & \multicolumn{4}{|c|}{ Yevmiye $[A k c ̧ e]$} & \multirow{2}{*}{ Açıklama } \\
\hline & 1526 & 1545 & 1557-58 & 1566 & \\
\hline $\begin{array}{c}\text { Kemal } \\
\text { Acem }\end{array}$ & 8 & - & 8 & 8 & Hazret-i Pâdişâh-ı âlem-penâh-birle gelmiş. \\
\hline Şah Kulu & 4 & - & - & - & Mislihu (Onun gibi) \\
\hline $\begin{array}{l}\text { Pars } \\
\text { Acem }\end{array}$ & - & - & 8 & 8 & - \\
\hline Toplam Kişi & 2 & - & 2 & 2 & \\
\hline
\end{tabular}

Müteferrik Ehl-i Hiref

\begin{tabular}{|c|c|c|c|c|c|}
\hline \multicolumn{6}{|c|}{ Cemấat-i Müteferrika-i Ehl-i Hiref } \\
\hline \multirow{2}{*}{ İsim } & \multicolumn{4}{|c|}{ Yevmiye $\left[A k_{c ̧} e\right]$} & \multirow{2}{*}{ Açıklama } \\
\hline & 1526 & 1545 & $\mathbf{1 5 5 7 - 5 8}$ & 1566 & \\
\hline $\begin{array}{l}\text { Hacı Pîrî } \\
\text { Haymedûz }\end{array}$ & 8 & - & - & - & $\begin{array}{l}\text { Tebriz'den sürgün gelüp Amâsiyye'de cihet olup } \\
\text { mukaddemâ Istanbul Hâssa Harcindan alup } \\
\text { hâliyâ mezkûr deftere ilhâk olunmus. Fî gurre- } i \\
\text { Receb sene } 929 \text { (16 Mayis 1523). Ber-mu- } \\
\text { ceb-i Rûznâme } \\
\text { (1526-1545 yılları arasında vefat etmiş } \\
\text { olabilir.) }\end{array}$ \\
\hline $\begin{array}{l}\text { Muhammed Ali } \\
\text { Haymeduzz }\end{array}$ & 10 & - & - & - & $\begin{array}{l}\text { Mislihu }(\text { Onun gibi) } \\
\text { (1526-1545 ylları arasında vefat etmiş } \\
\text { olabilir.) }\end{array}$ \\
\hline $\begin{array}{c}\text { Hacı Muhammed } \\
\text { Camcı }\end{array}$ & - & 10 & 12,5 & - & $\begin{array}{l}1515 \text { yılında Tebriz'den getirilen sanat- } \\
\text { kârlar arasındadır (TSMA, D.9784). } 1564 \\
\text { yoklamasında hayattadır. 1564-1566 yılla- } \\
\text { n1 arasında vefat etmiş olabilir. }\end{array}$ \\
\hline Toplam Kişi & 2 & 1 & 1 & - & \\
\hline
\end{tabular}

